\title{
How does urbanization affect perceptions and traditional knowledge of medicinal plants?
}

Cecilia Arjona-García', José Blancas', Leonardo Beltrán-Rodríguez², Citlalli López Binnqüist ${ }^{3}$, Hortensia Colín Bahena ${ }^{4}$, Ana Isabel Moreno-Calles ${ }^{5}$, José Antonio Sierra-Huelsz ${ }^{6}$ and Xavier López-Medellín ${ }^{1 *}$ (iD

\begin{abstract}
Background: The use and knowledge of medicinal plants play an essential role in community health in rural Mexico. Medicinal plants are part of the local heritage and provide a source of economic income. Nevertheless, knowledge of their use has declined due to factors like accelerated urbanization. Some authors have proposed that by reducing natural spaces, urbanization generates changes that impact the recognition, use, and management of natural resources. Here, we evaluate how urbanization affects the knowledge, use, and perception of medicinal plants in a Biosphere Reserve in Mexico.
\end{abstract}

Methods: Using a mixed methodology including quantitative and qualitative analyses, we generated a list of medicinal plants, methods of preparation, prevalence of illness, and use in two communities with different degrees of urbanization.

Results: A total of 217 medicinal plants were identified. The more urbanized community had greater knowledge of, and used, a larger number of introduced plant species, while the less urbanized community used and had more knowledge about wild plants. One of the factors explaining these differences was occupation, with people who work outdoors showing greater knowledge of wild plants.

Conclusions: Urbanization can lead to a loss of knowledge of the use and management of local wild species, with implications for the conservation of biocultural heritage. Substitution of native medicinal plants by introduced species shows disinterest and disuse in the local medicinal flora, which could be reflected in their ecosystems.

Keywords: Biocultural conservation, Cultural changes, Ethnobotany, Traditional knowledge, Tropical deciduous forest

\footnotetext{
* Correspondence: xImedellin@uaem.mx

'Centro de Investigación en Biodiversidad y Conservación (CIByC),

Universidad Autónoma del Estado de Morelos, Av. Universidad 1001, Colonia

Chamilpa, C.P, 62209 Cuernavaca, Morelos, Mexico

Full list of author information is available at the end of the article
}

(c) The Author(s). 2021 Open Access This article is licensed under a Creative Commons Attribution 4.0 International License, which permits use, sharing, adaptation, distribution and reproduction in any medium or format, as long as you give appropriate credit to the original author(s) and the source, provide a link to the Creative Commons licence, and indicate if changes were made. The images or other third party material in this article are included in the article's Creative Commons licence, unless indicated otherwise in a credit line to the material. If material is not included in the article's Creative Commons licence and your intended use is not permitted by statutory regulation or exceeds the permitted use, you will need to obtain permission directly from the copyright holder. To view a copy of this licence, visit http://creativecommons.org/licenses/by/4.0/ The Creative Commons Public Domain Dedication waiver (http://creativecommons.org/publicdomain/zero/1.0/) applies to the data made available in this article, unless otherwise stated in a credit line to the data. 


\section{Background}

Traditional knowledge of the use and management of natural resources is a reflection of the relationship between human communities and their physical, biotic, and cultural environment over time $[1,2]$. This relationship is mediated by the cultural, economic, and ecological context, making it dynamic and versatile [3, 4]. These changes can modify traditional knowledge, such that it grows, remains the same, or erodes [3]. This can affect how elements of nature are used and managed, as well as practices, customs, beliefs, and ideas $[5,6]$ at both the individual and group levels [4]. Consequently, there is a consensus that biodiversity conservation implicitly involves traditional knowledge $[7,8]$.

Some studies have shown that processes associated with modernization negatively affect the degree and depth of knowledge of natural resources; increasing educational level, migration, and urbanization are related to loss of the ability to recognize, name, use, and manage plant resources [9-11]. Urbanization is a complex economic process that entails social and environmental changes that occur over short time periods and often modify cultural patterns $[6,12]$. This process sometimes generates innovations in the culture that, in association with the acquisition of prestige, motivate the displacement of patterns of social behavior and organization [13]. At the same time, urbanization leads to drastic changes in people's lifestyles, perceptions, and sociability $[14,15]$, which can directly affect the use and management of natural resources.

Urbanization transforms land use and radically changes ecological patterns and processes [16]. Urbanization often includes the removal and logging of large areas of forests to make way for human settlements of various kinds [17]. Thus, urbanization results in a profound transformation of the environment, generating alterations in biogeochemical cycles, habitat fragmentation, and changes in the abundance, diversity, and composition of species $[16,18,19]$. It also generates changes in the ways of feeding and in the vocation of agroecosystems [20-22]. At a cognitive level, urbanization can lead to a disconnect between people and the natural environment, causing what Pyle (1993) [23] calls "the extinction of the experience."

In particular, urbanization can affect people's knowledge of medicinal plants, which includes recognizing, naming, using, and managing species in that use category. It has been hypothesized that urban communities, by having increased access to medical services, may abandon or reduce their use of medicinal plants to treat some illnesses and ailments [24, 25]. In addition, this loss of knowledge and abandonment of use could be due to a decrease in agricultural, agroforestry, and forested areas, since urbanization reduces the areas for medicinal plant collection. At the same time, urbanization decreases people's involvement in activities in natural environments and can lead to devaluation of and discrimination against traditional knowledge. Some authors have suggested that the decreased contact between people and their natural environment results in societies that are more tolerant of the progressive loss of biodiversity [26]. Therefore, the management and transmission of traditional knowledge to new generations is crucial not just for the preservation of cultural heritage, but also for the prevention of biodiversity loss [26].

The use of medicinal plants is one of the elements of traditional knowledge that, because it is linked directly to health, is particularly sensitive for local communities [27]. It is estimated that $80 \%$ of the population in developing countries use medicinal plant resources for primary care [28]. Their use persists in rural and urban areas as a result of the transmission of knowledge, mostly in verbal form and between generations [29]. At the same time, the lack of access to public health services in rural areas incentivizes the use of medicinal plants [24, 25].

Despite their importance, knowledge of medicinal plants is subject to several threats due to, among other factors, urbanization $[30,31]$. Urbanization leads to the loss of wild vegetation, reduction of the area dedicated to traditional agriculture, and transformation of natural areas for activities like commerce; at the same time, this contributes to cultural modification [32]. Land use change not only leads to the destruction of habitats of a variety of medicinal plants but also impacts the degree of knowledge of their management and uses. When medicinal plants no longer exist in the natural environment, the reflection on their use is also lost between one generation and the next $[11,33,34]$. Consequently, the use and management of medicinal plants could be modified by a reduction in the areas of collection and propagation, reluctance, and decrease in their use, as well as the perception of incompatibility between traditional and western medicine [27].

The general panorama of the effects of urbanization on the traditional knowledge of medicinal plants requires more research in order to clarify how certain factors associated with urbanization (access to official health services, migration, changing economic activities, etc.), affect the use of medicinal plants in traditional communities. It is important to document these processes in bioculturally megadiverse countries with a long tradition of use of medicinal plants and that currently face a scenario of loss of associated biocultural heritage due to, among other processes, urbanization.

The processes that deteriorate biocultural heritage are notorious in Mexico, one of the five most diverse countries worldwide [35], and where about 6,000 species of 
medicinal plants are used, of which at least 4,000 are collected from forests and jungles [36]. Despite this grand biocultural legacy resulting from thousands of years of interaction between diverse cultures and their environments [37], there are currently challenges that urgently need to be met. The country faces a public health emergency due to the obesity and diabetes epidemics, in addition to other diseases associated with sedentary lifestyle and increasing urbanization [38]. In addition, it is 43rd out of 194 countries in the rate of urbanization, with $80.2 \%$ of its inhabitants living in cities [39]. At the same time, it is ranked fifth worldwide in rates of deforestation [40], and land use change, including urbanization, has led to the destruction of ecosystems that harbor biodiversity, including species of medicinal plants.

In this study, we evaluate the knowledge of medicinal plants possessed by inhabitants of two communities with differing degrees of urbanization. At the same time, we explored the relationship between urbanization and the number of native and introduced species people knew, as well as sociocultural factors that influence species richness of medicinal plants used, comparing the relationships within and between communities.

This work was based on the premise that urbanization changes patterns of knowledge and use of medicinal flora, such that we expected inhabitants of the more urbanized community to know fewer species of medicinal plants and highlight introduced species, and that purchase would be the mode of acquisition of medicinal plants, all of which would suggest a loss of the knowledge of the local medicinal flora in this community. In contrast, we expected the less urbanized community to have more knowledge of local medicinal species, prefer native and wild species, and more frequently collect rather than purchase them.

\section{Methods}

\section{Description of the study area}

The study area is part of the Balsas river basin, a region in south-central Mexico from which most of the wild medicinal plants sold are extracted. This includes many

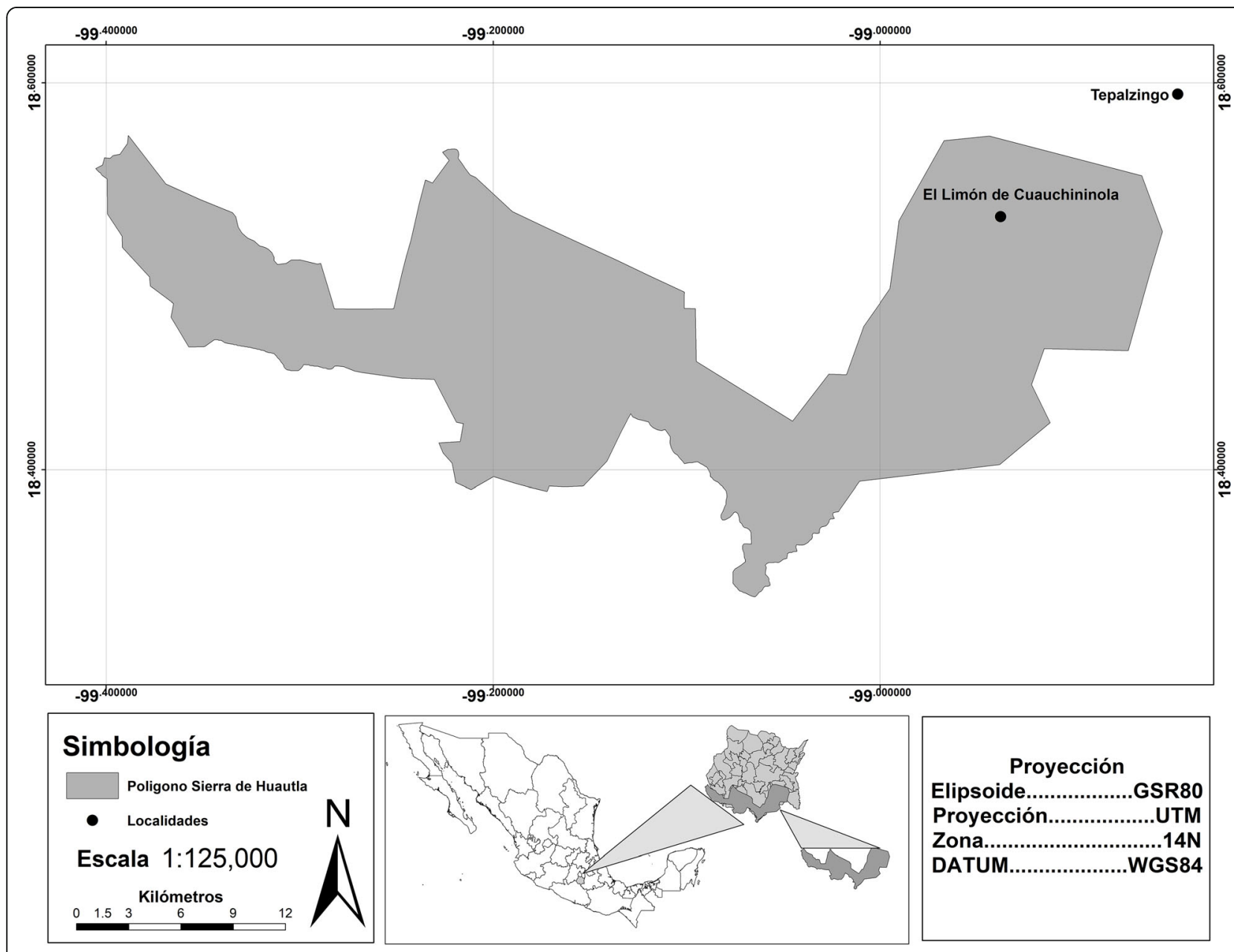

Fig. 1 Sierra de Huautla Biosphere Reserve (Reserva de la Biosfera Sierra de Huautla; REBIOSH) and location of the study localities 
markets and tianguis around the country, especially the Mercado de Sonora in Mexico City, which is perhaps the largest market for medicinal plants in Latin America [34, 41, 42]. In addition, this area has historically been a collection area for medicinal plants, in particular for many species that were used to pay tribute to MexicoTenochtitlan by the cultures and communities in the south of the state of Morelos [43]. Notable examples are copal (Bursera sp. [44];), jicaras (Crescentia sp. [45],) and linaloe (Bursera linanoe [46];). During the colonial period and until the last century, the area was an important collection area for medicinal plants, both in the Balsas River Basin (where tropical dry forest vegetation dominates), and in the Mixteca, a bioculturally diverse region which includes the three states of Guerrero, Puebla, and Oaxaca. The village of Tepalcingo is a very important settlement historically. It has pre-Hispanic roots, founded in 1272, and its inhabitants are widely known for their knowledge of the use and management of medicinal plants [47].

The study area is near the border of the Sierra de Huautla Biosphere Reserve (Reserva de la Biosfera Sierra de Huautla; REBIOSH), in the state of Morelos, Mexico (Fig. 1). The reserve was decreed in 1999 and has an area of 59,030 hectares. It is covered almost entirely by TDF $[48,49]$, which is characterized by trees with an average height of $10 \mathrm{~m}$ that lose their leaves during the dry season [50]. The total population within the reserve is 25,356 inhabitants [51] in rural communities with high marginalization indexes due to little access to health, transportation, and education services and limited employment opportunities [52].

There are 939 species of vascular plants reported in the area, of which $602(56 \%)$ are used by the communities to meet health, food, and shelter needs, among other uses [48]. About 400 species (66\%) are medicinal plants that can be used to help resolve some health issues, since there are no public health services in $60 \%$ of the communities [48, 53].
We selected two communities-El Limón de Cuauchichinola (ELC) (within the REBIOSH) and Tepalcingo (TGO; in the area of influence of the REBIOSH) - which differ in their degree of urbanization (Table 1). ELC was founded in 1900 by a migrant population from other localities in the vicinity, and in 1929 was consolidated as an ejido (a mode of collective community-based land ownership in Mexico). ELC has a population of 129 and has a public primary school and local government house. A portion of its youth and adult population emigrate temporarily to the USA in search of employment opportunities. TGO is the municipal seat of the municipality of the same name and has a population of 12,053 inhabitants. It was founded in 1272 by native tribes, but it was not until 1869 that it was considered a municipality of Morelos. This community acts as a hub of distribution and trade in the region, and it is visited by people from different communities of southern Morelos to buy and sell products, which also makes it a destination for people who have migrated from other neighboring communities.

The urbanization indicators that we used were the economic activities, availability of healthcare services, and average level of education. The socioeconomic data were obtained from the 2010 census [51] and the $\mathrm{Na}$ tional Statistical Directory of Economic Units (Directorio Estadístico Nacional de Unidades Económicas) [52]. ELC is less urbanized than Tepalcingo, since its inhabitants depend almost exclusively on primary sector activities (Table 1, Fig. 2). TGO is a more urbanized community, since its inhabitants mainly work in the tertiary sector, such as commercialization and services (Table 1, Fig. 3).

\section{Stratified random sampling}

In order to analyze the existence of an urbanization gradient that could impact knowledge of medicinal plants, we did stratified random sampling, differentiating regions within each community following the sampling design proposed by Pagaza [9]. We defined two regions-"central" and "peripheral" in each community.

Table 1 Demographic data for the communities of El Limón de Cuauchichinola (ELC) and Tepalcingo (TGO)

\begin{tabular}{|c|c|c|c|c|}
\hline Community/location & $\begin{array}{l}\text { Number of } \\
\text { inhabitants/ } \\
\text { no. of } \\
\text { homes }\end{array}$ & Economic activities & Services & $\begin{array}{l}\text { Average } \\
\text { education } \\
\text { (years) }\end{array}$ \\
\hline $\begin{array}{l}\text { ELC/18³1' } 51^{\prime \prime} \mathrm{N}, 98^{\circ} \\
56^{\prime} 15^{\prime \prime} \mathrm{W},(1259 \text { masl), } \\
28.5 \mathrm{~km} \text { from municipal } \\
\text { seat }\end{array}$ & $129 / 37$ & $\begin{array}{l}\text { Seasonal agriculture, extensive livestock rearing, } \\
\text { gathering of non-timber forestry products }\end{array}$ & $\begin{array}{l}37 \text { homes in the community, all occupied, of } \\
\text { which only } 28 \text { have electricity, running water, } \\
\text { and public sewer lines. Public primary school } \\
\text { and once monthly brigade offering free } \\
\text { medical appointments }\end{array}$ & 5.1 \\
\hline $\begin{array}{l}\mathrm{TGO} / 18^{\circ} 35^{\prime} 47^{\prime \prime} \mathrm{N}, 98^{\circ} \\
50^{\prime} 237^{\prime \prime} \text { W, (1160 masl). } \\
\text { Municipal seat. }\end{array}$ & $12,053 / 3674$ & $\begin{array}{l}\text { Functions as a center for commerce and } \\
\text { distribution of products and has approximately } \\
370 \text { different services, among which small } \\
\text { shops and are the most frequent. }\end{array}$ & $\begin{array}{l}2382 \text { homes have electricity, running water, } \\
\text { and public sewer lines. Has education, public } \\
\text { healthcare, and private medical practices, as } \\
\text { well as wellness programs and public } \\
\text { transportation }\end{array}$ & 7.62 \\
\hline
\end{tabular}



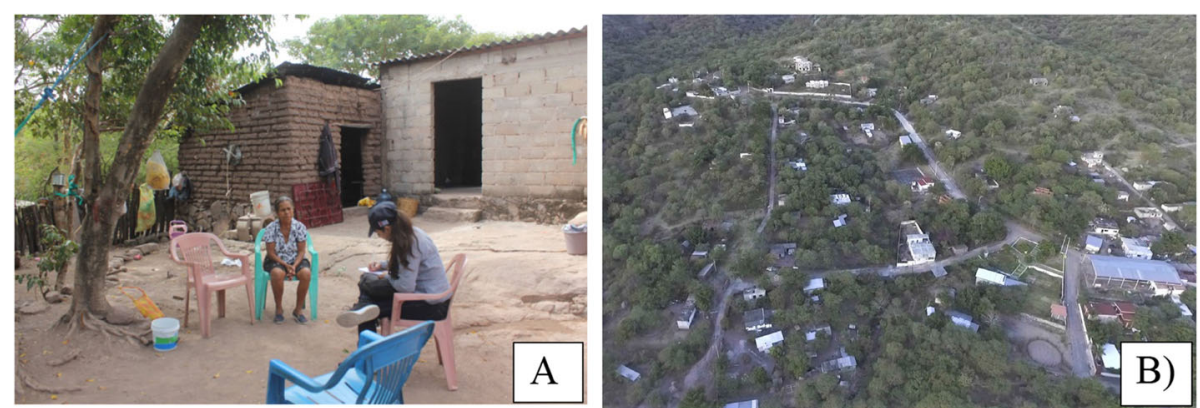

Fig. 2 Community of El Limón de Cuauchichinola. A Interview with community members. B General panorama of the community. Photos: A C. Arjona, B Nextia multimedia

The central region referred to the area where the community's administrative services were concentrated, while the periphery was defined as the areas near zones of agriculture, agroecosystems, and wild vegetation.

\section{Free listing and semi-structured interviews}

We used free listing to document the number of medicinal plant species known by the inhabitants of each community, with 28 and 77 people in ELC and TGO respectively [54, 55]. We did a semi-structured interview [54] with the same people in order to collect personal data (name, age, sex, occupation, and birthplace), and data on medicinal plants, including their use, methods of preparation, parts used, method of acquisition (collection or purchase), conditions for which they are used, and if the interviewee had consulted with specialists in medicinal plants or traditional medicine. Saturation or redundancy of information was used to determine when the appropriate sample size was reached [56], and a nonparametric $t$ test for unbalanced data was used in order to avoid biases in the results due to the difference in the total number of interviews per community.

\section{Structured interview}

Using information from the stratified random sampling, we located 16 key informants ( 7 in ELC and 9 in TGO) who were recognized for their experience in the management of medicinal plants. We carried out structured interviews with these informants to obtain detailed information about the species of medicinal plants used, frequent ailments, plant parts used, method of acquisition, and opinions and perceptions concerning the persistence or erosion of the knowledge and use of medicinal plants [54].

\section{Ethnobotanical walks}

To determine the taxonomic identities of the species recounted, both in the listing and in the structured interview, we carried out six ethnobotanical walks [57] in zones of wild and secondary vegetation, as well as agroecosystems in both communities (4 in TGO and 2 in ELC). The botanical specimens were collected and identified and deposited in the "HUMO" herbarium at the Center for Research in Biodiversity and Conservation (Centro de Investigación en Biodiversidad y Conservación, CIByCUAEM).
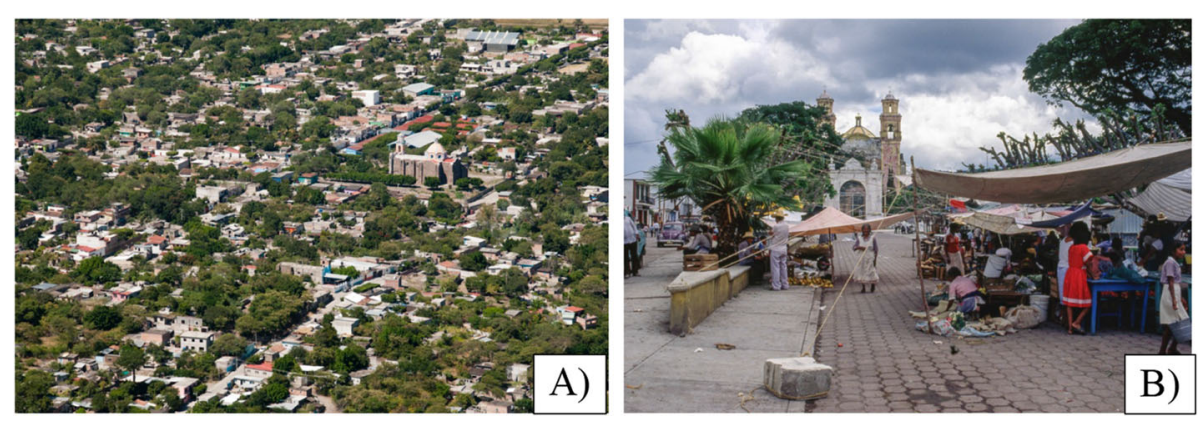

Fig. 3 A General overview of the community of Tepalcingo. B Commercial activities in the center of the community. Photographs: A Sistema de Archivos Compartidos UAEM-3Ríos 


\section{Quantitative analysis of information}

In order to determine whether there were differences in the knowledge of medicinal plants between the two communities, we analyzed the results of the free listing and semi-structured interviews using Wilcoxon's $W$ test for samples with asymmetrical distribution. This analysis was done for the total number of species named, then separately for the number of native, introduced, and wild species mentioned. The differences were evaluated between communities, regions, occupations, sex, and birthplace of the interviewee. The analyses were done in SPSS software, version 24.0 [58].

Using the data from the free listing and the semistructured interviews, we constructed a database with 16 variables that considered the socioeconomic information and degree of knowledge of medicinal plants in the interviewed populations of the two communities. In order to characterize the differences in knowledge of medicinal plants depending on the degree of urbanization within and between the communities, we did a discriminant function analysis using SPSS software, version 24.0 [58].

\section{Qualitative analysis of information}

We did a qualitative analysis of the information from the interviews with key informants in order to characterize the ideas, comments, and perceptions associated with knowledge of medicinal plants. This approach from the social sciences guides the research question, allowing for deep exploration of the changes in knowledge of medicinal plants from the perspective of people from the localities who have broad experience with their management [59]. This methodology is based on the notion that reality is socially constructed, and that people therefore give meaning to social and natural phenomena according to their perceptions of the world [60-62]. The interviews from the two communities were transcribed and codified using the program ATLAS.ti version 7.5 [63], organizing the information according to the perceptions of the key informants into four coded categories: treatment preferences, teaching-learning, availability of medicinal plants, and problems. The codification of the information consisted in an exploratory line-by-line reading and selection of particular data in order to reduce the information into a format that was manageable for analysis and interpretation. We also created a perception map linking the responses obtained and enumerating the responses that were similar among interviewees [64-67]. This map was included because it serves as a graphical summary of the different perceptions and helps structure the narrative of the results and discussion.

\section{Results}

In the two communities studied, we recorded a total of 269 common names of medicinal plants, which correspond to 217 species, of which $148(68 \%)$ are native to Mexico, 79 (36\%) are naturally distributed in the study area, and $69(31 \%)$ are introduced. The total richness was grouped into 70 botanical families, and the families with the largest number of species were Fabaceae, (28

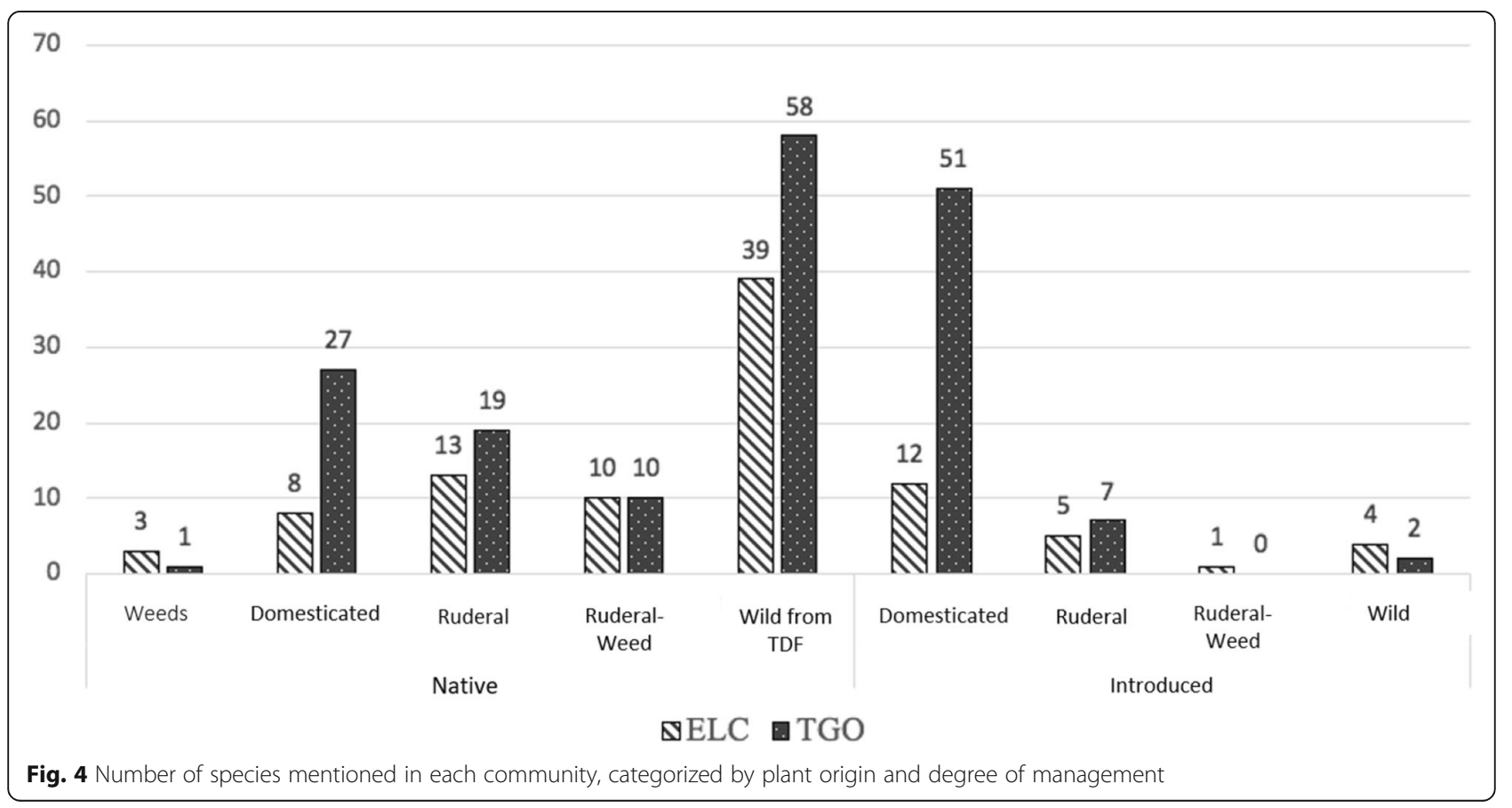


species), Asteraceae (21), Lamiaceae (11), Solanaceae (9), and Malvaceae (8).

\section{Differences in the degree of knowledge of medicinal plants by community}

In ELC, 95 species of medicinal plants were mentioned, distributed in 46 botanical families, of which 73 are native to Mexico (42\%), 39 are considered part of the tropical dry forest (51\%), and 22 are introduced (12\%) (Fig. 4). In TGO, 175 species of medicinal plants were named, which are distributed in 71 botanical families, 115 are native to Mexico (66\%), 60 species are introduced (34\%), and 58 are tropical dry forest species (Fig. 4).

Wilcoxon's $W$ test showed significant differences between the communities (ELC vs. TGO) at all levels of the analysis of knowledge of medicinal plants (total number of species mentioned and number of native, introduced, and wild species). The region factor showed differences between the center and periphery of the two communities in the total number of species, the number of native species, and the number of wild species, but not the number of introduced species. Women mentioned more introduced species than men ( $W=1,314, p$ $=0.002$ ), with no differences in the total, native, or wild species (Table 2). People that worked in the field mentioned more wild species than homemakers $(W=704, p$ $=0.016)$. There were no significant differences when comparing among birthplaces (Table 2).

Knowledge of medicinal plants and urbanization gradient The discriminant function analysis showed that people's knowledge of medicinal plants was affected by urbanization. As shown in Table 3, the first two functions explained $92 \%$ of the variation, with the first explaining $77.2 \%$ and the second $14.8 \%$. The grouping of the interviewees in discriminant function 1 was statistically significant, which was also confirmed by the canonical correlation value and Wilk's lambda. Figure 5 shows that the interviewees were distributed along an urbanization gradient, in which the periphery of ELC is shown in the yellow oval on the left-hand side of the graph, followed by interviewees from the central zone of ELC (red oval). The distribution of the interviewees from the periphery of TGO (gray oval) and from the center of TGO (black oval) were interspersed with each other. The most important variables in Function 1 (Table 4) were age of informants, number of spp. collected, total spp. recorded in our research, number of native spp. mentioned, total native spp. recorded, number of wild spp. reported, and the use of the species. These all had a negative sign, which means that people located toward the right-hand side of the graph (TGO) had on average lower age, referred to a lower number of species collected, and a lower number of native and wild species compared to people located on the left-hand side of the graph (ELC). Variables with positive values were the number of species purchased, domesticated, and introduced species. Thus, interviewees located on the righthand side of the graph reported, on average, purchasing medicinal plants more frequently, and using a larger number of domesticated and introduced species.

Table 5 shows that $61.3 \%$ of the total interviewees were correctly classified according to the degree of urbanization assigned to each community. The majority of interviewees were correctly classified as inhabitants of the periphery of ELC (77.8\% assigned correctly), the center of TGO (63.9\%), the periphery of TGO $(56.1 \%)$, or the center of ELC (45.5\%).

Table 2 Results of Wilcoxon's $W$ test of differences in knowledge of medicinal plants between communities (ELC, El Limón de Cuauchichinola; TGO, Tepalcingo). Bold text indicates significant differences $(P<0.01)$

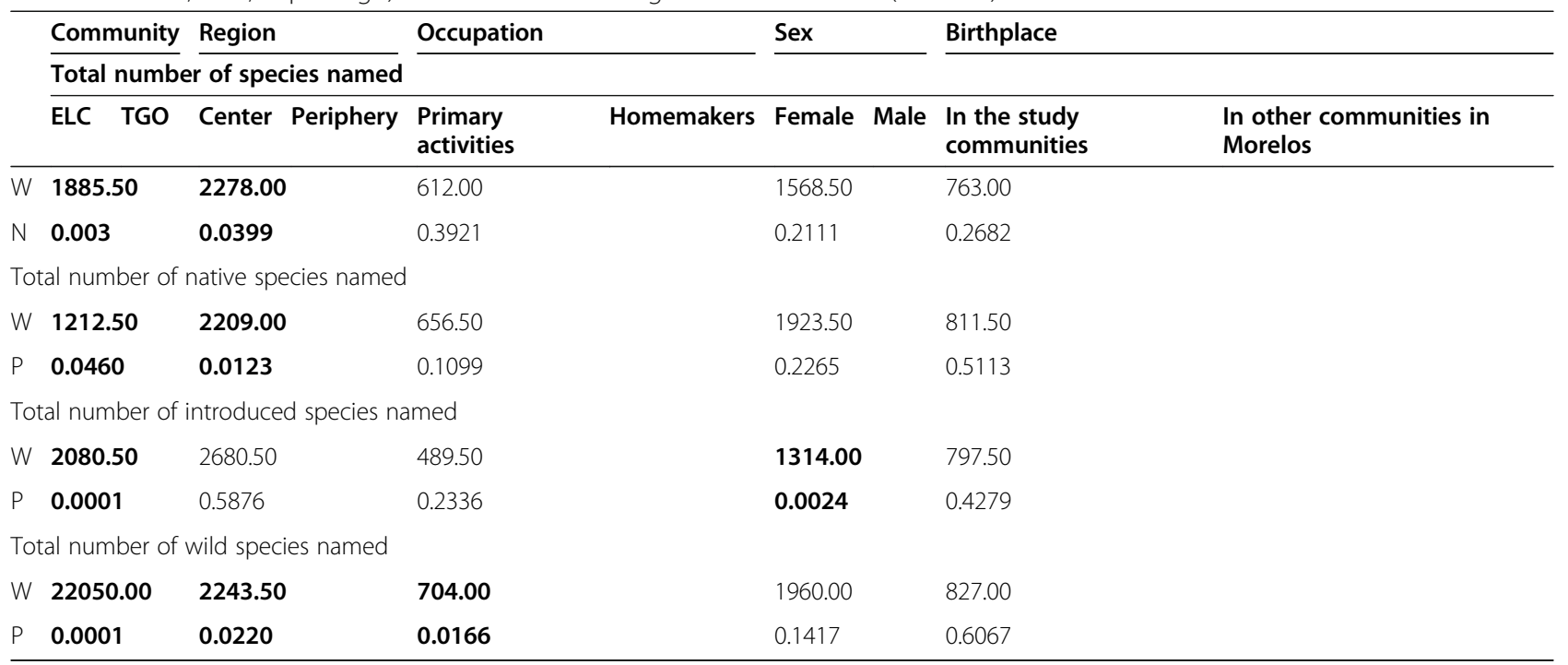


Table 3 Autovalues and Wilk's lambda from the discriminant functions analysis, using as a grouping variable the center and periphery regions of each study community

\begin{tabular}{lllll}
\hline Function & Autovalue & \% variance & Cumulative \% & Canonical correlation \\
\hline 1 & 1.081 & 77.2 & 77.2 & 0.721 \\
2 & 0.208 & 14.8 & 92.0 & 0.415 \\
Test of functions & Wilk's lambda & Chi-squared & df & Sig. \\
1 to 2 & 0.358 & 98.658 & 42 & 0.000 \\
2 & 0.745 & 28.301 & 26 & 0.344 \\
\hline
\end{tabular}

\section{Perceptions and qualitative analysis of knowledge of} medicinal plants in different urbanization contexts

In ELC, seven key informants were interviewed-two men and five women between 54 and 73 years of age. Most of these people were born in the community and their occupation was in the primary sector (agriculture, livestock, gathering) and in the home. These people preferred to use medicinal plants to cure illness, since these are abundant in their communities and are a free alternative for the treatment of many ailments. However, they mentioned that if the use of these plants does not lead to improvement, or with specific conditions such as bites/stings or severe illness, they must travel to another more urban community $(63-\mathrm{km}$ distance, almost a 2-h journey) to seek treatment at a health clinic that is open all year round which offers services that are not available in the community; this travel has time and monetary costs.

The majority of the interviewees in ELC learned to use medicinal plants directly from family members or by observing their use by other people (4). However, none had transmitted their own knowledge to others, and they mentioned that knowledge of medicinal plants is being lost since inhabitants prefer the speed of allopathic medicine, because people are no longer interested in these plants or do not consider them effective, or because they are lazy or lack the discipline to prepare the remedies. The key informants from ELC did not consider themselves traditional medical practitioners, but the population did recognize them as experts and occasionally consult them on their knowledge of medicinal plants, such that they did play an important role in the

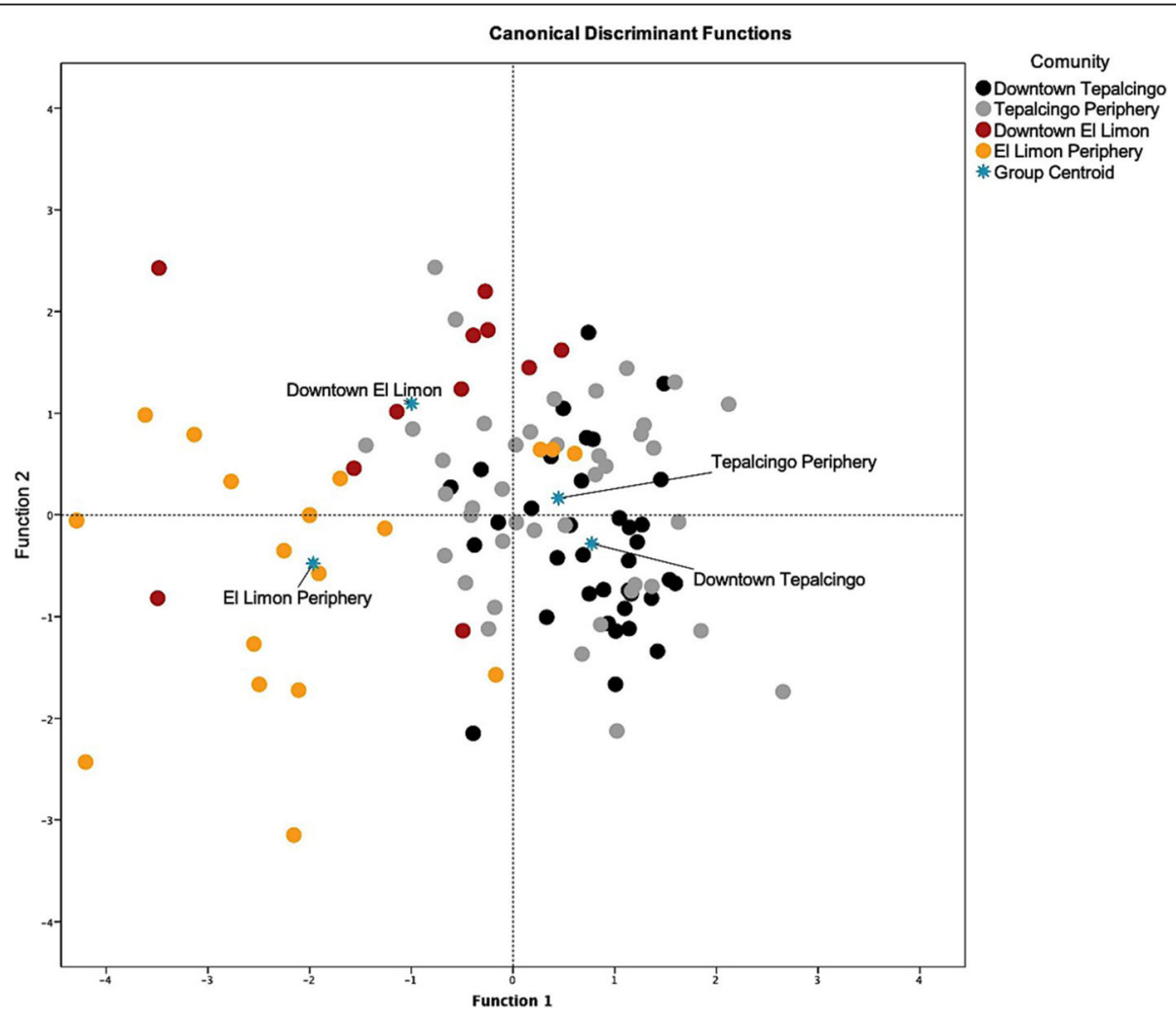

Fig. 5 Distribution of interviewees according to degree of urbanization 
Table 4 Relative importance of the variables studied in the first two discriminant functions

\begin{tabular}{lll}
\hline \multicolumn{3}{l}{ Standardized canonical discriminant function coefficients } \\
\hline Variable & $\mathbf{1}$ & \\
& Function & \\
Sex & -0.1002 & -0.0953 \\
Age & $-\mathbf{3 . 1 1 9 3}$ & 6.4347 \\
Birthplace & -0.1734 & 0.1926 \\
Ocupation & 0.3962 & 0.3197 \\
Number of species & -0.7418 & -0.6630 \\
Number of native species & $-\mathbf{1 . 4 6 9 7}$ & -0.0436 \\
Number of introduced species & 0.7278 & -0.6194 \\
Number of wild TDF species & $\mathbf{- 1 . 2 7 8 4}$ & 0.3881 \\
Number of domesticated species & $\mathbf{1 . 0 0 7 6}$ & -1.0529 \\
Number of ruderal species & -0.1274 & -0.1139 \\
Number of herbaceous species & -0.0989 & -0.1353 \\
Number of ruderal and herbaceous species & -0.3304 & 0.0692 \\
Number of species collected & $\mathbf{- 1 . 7 4 3 9}$ & -0.5615 \\
Number of species purchased & $\mathbf{1 . 0 7 4 9}$ & -0.0085 \\
& 0.3174 & -0.1511 \\
\hline
\end{tabular}

Bold text indicates the most important variables in the discriminant function

community (Fig. 6). The ELC interviewees mentioned 81 ailments that are cured with medicinal plants (Table 6). The most frequently mentioned were stomachache $(30$ mentions), diarrhea and wounds (25 each), cystitis (13), inflammation (12), and gastritis and postpartum ailments (11 each). The most mentioned methods of preparation were by boiling the plant to make teas or infusions to drink with 58 species, followed by the cleaning of wounds with the infusions of 12 species (Table 7).

In TGO, nine key informants were interviewed-five women and four men, between the ages of 39 and 72 . They held diverse occupations, from the home to traditional medicine practitioners. The majority preferred to use only medicinal plants to treat illness, since they were unfamiliar with the substances used in allopathic medicine (5), while the remaining informants preferred to combine traditional medicine with allopathic medicine.

The informants learned about the use of medicinal plants from a family member or by observing others. Several were transmitting that knowledge to their children, although many were not interested in learning, leading the informants to consider that knowledge of the use of medicinal plants was being lost in their community. In addition to the lack of interest in learning about these resources, they mentioned that these plants were disappearing and that the clinic physicians advised their patients against using medicinal plants. However, they also mentioned that one characteristic that has helped to maintain this knowledge is that the use of medicinal plants is a free alternative for those that do not have money to buy allopathic medications. They also mentioned that medicinal plants were most available in surrounding patches of native vegetation. Additionally, they commented that at the local market they could acquire many varieties of medicinal plants from other regions and even other countries. There were 127 frequently mentioned diseases or ailments treated with medicinal plants in this community, among them, kidney discomfort (32 mentions), diabetes (30), cough (26), stomachache (25), and wounds (21). They used 107 species in infusions, 28 by placing the plant directly on the painful area, and 28 in liquified preparations. Some other uses were least frequently mentioned, such as syrups and vaporizations with 2 mentions each, and using a collar made with lemons with 1 mention (Table 7).

Most of the interviewees said that they attend health clinics only when their condition does not improve with natural treatments or when they are suffering from a serious illness. In addition, medicinal plants were a source of supplementary income for these informants and their families, although the number of patients had

Table 5 Classification of interviewees according to the urbanization gradient in the study communities. The data show raw and percentage values $[33,36]$

\begin{tabular}{llllll}
\hline Comunidad & \multicolumn{2}{l}{ Predicted group membership } & & Total \\
\cline { 2 - 5 } & Tepalcingo Center & Tepalcingo Periphery & El Limón Center & El Limón Periphery \\
\hline Tepalcingo Center & 23 & 13 & 0 & 0 & 36 \\
Tepalcingo Periphery & 15 & 23 & 2 & 2 & 41 \\
El Limón Center & 1 & 3 & 5 & 14 & 11 \\
El Limón Periphery & 4 & 0 & 0 & $0 \%$ & 18 \\
Tepalcingo Center & $63.9 \%$ & $36.1 \%$ & $0 \%$ & $2.4 \%$ & $100 \%$ \\
Tepalcingo Periphery & $36.6 \%$ & $56.1 \%$ & $4.9 \%$ & $18.2 \%$ & $100 \%$ \\
El Limón Center & $9.1 \%$ & $27.3 \%$ & $45.5 \%$ & $77.8 \%$ & $100 \%$ \\
El Limón Periphery & $22.2 \%$ & $0 \%$ & $0 \%$ & & $100 \%$ \\
\hline
\end{tabular}

$61.3 \%$ of original grouped cases correctly classified 


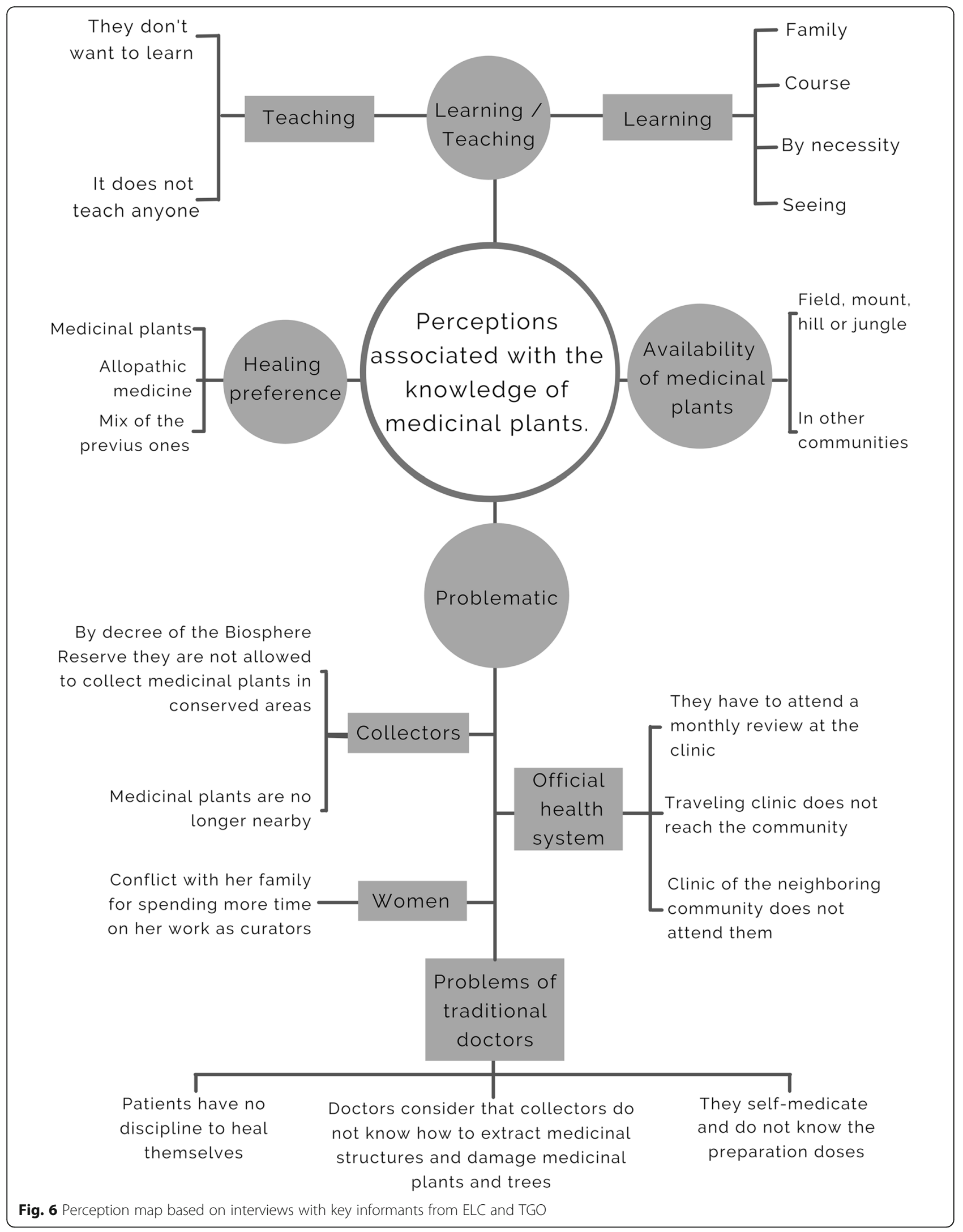


Table 6 Average number of species mentioned by occupation

\begin{tabular}{lllll}
\hline Occupation & TGO & & ELC & \\
\cline { 2 - 5 } & Average & Standard deviation & Average & Standard deviation \\
\hline Primary sector & 7.66 & 3.01 & 10.06 & 4.93 \\
Homemaker & 10.625 & 6.13 & 9.53 & 6.38 \\
\hline
\end{tabular}

decreased in recent years due to the increase in the availability of allopathic medicines in the community. However, thanks to the community's confidence in their abilities, they continued to provide their services:

"...the thing is that people lose confidence in the doctors, because they say one thing, then they want to treat you for something else... I had pain from an infection I had, and the doctor checked me out and said it was my gall bladder, that I needed an operation, but I didn't listen to him, I took some herbs I prepared and now I'm fine...but it takes time, and nowadays people don't want to be healed, they want everything quick, and I tell them that if they want to heal, they have to take the treatment for at least a month..." Key informant from TGO (Fig. 6).

\section{Discussion}

\section{The importance of tropical dry forest (TDF) in the} provision of medicinal plants

The region where the study communities are located provides a considerable percentage of the medicinal plants that are sold in Mexico [68]. This indicates the importance of these resources in the culture and economy of the inhabitants of this natural reserve, as well as the contribution of the tropical dry forest (TDF) to the treatments used in, and the general persistence of, the practice of traditional medicine. In this study, we recorded a total of 217 species of medicinal plants, which correspond to $72.33 \%$ of the flora reported for the region by Maldonado-Almanza [16]. TDF is the dominant vegetation type, providing medicinal plants to the Sonora Market (Mercado de Sonora) in Mexico City, which is one of the most important markets for medicinal plants in Latin America [68]. Thus, the TDF is of great environmental, social, and economic importance in the conservation of these resources [36, 69-71].

This high percentage of medicinal plants $(72.3 \%)$ indicates that both communities possess a fair amount of knowledge about these species due to the role they play in health and the local population's need for viable and low-cost healthcare options. This can be explained by the fact that only $40 \%$ of the communities within the reserve have permanent public healthcare installations like those available in TGO; the inhabitants of less urbanized communities, like ELC, must invest time and money in traveling to the municipal seat to receive these services $[4,48,72]$. It is possible that these differences in access to healthcare also reflect asymmetry in knowledge of medicinal plants between the two communities.

Medicinal plants are the most important use category among the useful plants of Mexico [73] and the second most important among the group of species considered nontimber forest products (NTFPs) [ 74]. This importance is reflected by the number of ailments and treatments for which these plants are used by different local cultural groups [73]. The most represented botanical families in this study contain a large variety of useful secondary compounds in leaves, stems, bark, flowers, and fruits, in addition to being some of the most represented families in this type of vegetation [47, 73]. Species such as Amphipterygium adstringens (Schltdl.) Standl., Eysenhardtia polystachya (Ortega) Sarg., Haematoxylum brasiletto $\mathrm{H}$. Karst., and Crescentia alata Kunth had the highest importance and frequency of use, which is consistent with other studies from the study area and TDF more generally $[36,53,71,75]$.

\section{Urbanization negatively affects the level of knowledge of locally distributed medicinal plants}

In contrary to our expectation, in this study, we identified that the most urbanized community had greater overall knowledge of medicinal plants (TGO $175 \mathrm{spp}$. vs. ELC 95 spp.). This result was consistent among different criteria used to analyze the degree of knowledge of medicinal plants [11], such as the number of species mentioned, the number of native species, and the number of wild species (Table 2). This is probably related to the fact that TGO has a long history as a hub of regional distribution of medicinal plants and because it is the location of a market dating back to prehispanic times, in which merchants from all over the country gather to sell NTFP including crafts, medicinal plants, seasonal foods, utensils, beverages, etc. [76-78]. This fair generates commercial relationships and reinforces symbolic and cultural aspects that contribute to adaptation and innovation in traditional health practices as well as fomenting knowledge of medicinal plants among mestizo and semi-urban populations $[9,72,79,80]$. Such events, Vandebroek and Balick [79] point out, allow relatively urbanized communities to maintain a large amount of knowledge of medicinal plants due to demographic and historical dynamics that often buffer the loss of this knowledge. 
Table 7 All recorded plants and their uses

\begin{tabular}{|c|c|c|c|c|c|c|}
\hline Species & $\begin{array}{l}\text { Common } \\
\text { name }\end{array}$ & $\begin{array}{l}\text { Origin (1: } \\
\text { native, 2: } \\
\text { introduced) }\end{array}$ & $\begin{array}{l}\text { Number } \\
\text { of } \\
\text { mentions } \\
\text { (ELC) }\end{array}$ & $\begin{array}{l}\text { Number } \\
\text { of } \\
\text { mentions } \\
\text { (TGO) }\end{array}$ & Use & Preparation methods \\
\hline $\begin{array}{l}\text { Acacia angustissima } \\
\text { (Mill.) Kuntze }\end{array}$ & Timbre & 1 & 5 & 4 & Stomachache, acne & Tea, machacado \\
\hline $\begin{array}{l}\text { Acacia bilimekii } \\
\text { J.F.Macbr. }\end{array}$ & Tehuixtle & 1 & 0 & 2 & Cold sore, bruxism & Chewed \\
\hline $\begin{array}{l}\text { Acacia farnesiana } \\
\text { (L.) Willd. }\end{array}$ & Huizache & 1 & 1 & 6 & $\begin{array}{l}\text { Cold sore, bruxism, kidney stones, } \\
\text { prostate, liver }\end{array}$ & $\begin{array}{l}\text { Tea, applied to affected } \\
\text { area, placed with salt, } \\
\text { chewed, smeared }\end{array}$ \\
\hline $\begin{array}{l}\text { Acalypha aristata } \\
\text { Kunth }\end{array}$ & $\begin{array}{l}\text { Hierba del } \\
\text { cancer }\end{array}$ & 1 & 1 & 0 & Wounds, diuretic, kidneys, gastric ulcer & Tea \\
\hline $\begin{array}{l}\text { Acosmium } \\
\text { panamense (Benth.) } \\
\text { Yakovlev }\end{array}$ & Chichiqui & 1 & 0 & 1 & Psoriasis & Washing \\
\hline $\begin{array}{l}\text { Agave angustifolia } \\
\text { Haw. }\end{array}$ & Maguey & 1 & 0 & 1 & Wounds & Drops over wound \\
\hline $\begin{array}{l}\text { Agave salmiana } \\
\text { Otto ex Salm-Dyck }\end{array}$ & $\begin{array}{l}\text { Maguey de } \\
\text { Pulque }\end{array}$ & 1 & 0 & 1 & Cancer prevention & Tea \\
\hline Allium cepa L. & Cebolla & 2 & 0 & 4 & $\begin{array}{l}\text { Diabetes, cough, teething pain in babies, } \\
\text { tonsillitis }\end{array}$ & Placed on feet, tea \\
\hline Allium sativum $\mathrm{L}$. & Ajo & 2 & 1 & 6 & $\begin{array}{l}\text { Cough, diabetes, teething pain in babies, } \\
\text { scorpion sting }\end{array}$ & In alcohol, eaten, tea \\
\hline Aloe vera (L.) Burm.f. & Sábila & 2 & 3 & 28 & $\begin{array}{l}\text { Prostate, promote weight loss, kidneys, } \\
\text { gastritis, wounds, diabetes, menstrual } \\
\text { cramps, gastric ulcer, inflammation, skin } \\
\text { burns, hair health, postpartum, high } \\
\text { blood pressure, kidneys, stomachache, } \\
\text { cancer }\end{array}$ & $\begin{array}{l}\text { Liquified, drink with milk, } \\
\text { placed on feet, juice, } \\
\text { patches, applied to affected } \\
\text { area, eaten, grilled, } \\
\text { smeared, baths }\end{array}$ \\
\hline $\begin{array}{l}\text { Amphipterygium } \\
\text { adstringens (Schltdl.) } \\
\text { Standl. }\end{array}$ & Cuachalalate & 1 & 23 & 60 & $\begin{array}{l}\text { Wounds, gastritis, kidneys, cancer, } \\
\text { inflammation, lungs, rash, kidney stones, } \\
\text { ulcers, menstrual cramps, stomachache, } \\
\text { diarrhea }\end{array}$ & $\begin{array}{l}\text { Boiled, place dried and } \\
\text { ground on area with pain, } \\
\text { washing, baths, tea, wine }\end{array}$ \\
\hline $\begin{array}{l}\text { Ananas comosus (L.) } \\
\text { Merr. }\end{array}$ & Piña & 2 & 0 & 3 & Diabetes, uric acid, kidney stones & Liquified \\
\hline Annona muricata $\mathrm{L}$. & Guanábana & 2 & 0 & 6 & High blood pressure, cancer, diabetes & Tea, eaten \\
\hline $\begin{array}{l}\text { Apoplanesia } \\
\text { paniculata C.Presl }\end{array}$ & Escobilla & 1 & 0 & 1 & Diarrhea & Tea \\
\hline $\begin{array}{l}\text { Aristolochia } \\
\text { subclausa S.Watson }\end{array}$ & Tlacopatle & 1 & 0 & 1 & Foot pain & Applied to affected area \\
\hline $\begin{array}{l}\text { Artemisia } \\
\text { absinthium L. }\end{array}$ & Ajenjo & 1 & 0 & 2 & Stomachache, bile & Tea \\
\hline $\begin{array}{l}\text { Artemisia } \\
\text { ludoviciana subsp. } \\
\text { mexicana (Willd. ex } \\
\text { Spreng.) D.D.Keck }\end{array}$ & Estafiate & 1 & 0 & 4 & Stomachache, diarrhea & Tea \\
\hline $\begin{array}{l}\text { Artocarpus } \\
\text { heterophyllus Lam. }\end{array}$ & Yaca & 2 & 0 & 1 & Anemia & Tea \\
\hline Arundo donax L. & $\begin{array}{l}\text { Cañaveral/ } \\
\text { Carrizo }\end{array}$ & 2 & 2 & 2 & Kidneys, lungs, pain & Boiled, tea \\
\hline $\begin{array}{l}\text { Asclepias curassavica } \\
\text { L. }\end{array}$ & $\begin{array}{l}\text { Venenillo, } \\
\text { algodoncillo }\end{array}$ & 1 & 1 & 1 & Cold sores & Applied to affected area \\
\hline $\begin{array}{l}\text { Asterohyptis } \\
\text { stellulata (Benth.) } \\
\text { Epling }\end{array}$ & Chia & 1 & 0 & 1 & Diarrhea & Tea \\
\hline Avena sativa $L$. & Avena & 2 & 0 & 3 & Blood pressure & Liquified, tea \\
\hline
\end{tabular}


Table 7 All recorded plants and their uses (Continued)

\begin{tabular}{|c|c|c|c|c|c|c|}
\hline Species & $\begin{array}{l}\text { Common } \\
\text { name }\end{array}$ & $\begin{array}{l}\text { Origin (1: } \\
\text { native, } 2: \\
\text { introduced) }\end{array}$ & $\begin{array}{l}\text { Number } \\
\text { of } \\
\text { mentions } \\
\text { (ELC) }\end{array}$ & $\begin{array}{l}\text { Number } \\
\text { of } \\
\text { mentions } \\
\text { (TGO) }\end{array}$ & Use & Preparation methods \\
\hline $\begin{array}{l}\text { Azadirachta indica } \\
\text { A. Juss. }\end{array}$ & Neem & 2 & 1 & 23 & $\begin{array}{l}\text { Diabetes, kidneys, pain in hands, } \\
\text { circulation, stress }\end{array}$ & Boiled, capsules \\
\hline $\begin{array}{l}\text { Barkleyanthus } \\
\text { salicifolius (Kunth) } \\
\text { H.Rob. \& Brettell }\end{array}$ & Azumiate & 1 & 0 & 3 & Energetic cleansing & Rubbed on body \\
\hline $\begin{array}{l}\text { Bidens bipontina } \\
\text { Sherff }\end{array}$ & Acetillo & 1 & 0 & 0 & Wounds & Smeared \\
\hline Bidens odorata Cav. & Aceitillo & 1 & 2 & 1 & Wounds & Applied to affected area \\
\hline $\begin{array}{l}\text { Bougainvillea glabra } \\
\text { Choisy }\end{array}$ & Bugambilia & 2 & 2 & 15 & Cough, rash, colds & Boiled, tea, baths \\
\hline $\begin{array}{l}\text { Bouvardia ternifolia } \\
\text { (Cav.) Schltdl. }\end{array}$ & Clavillo & 1 & 3 & 0 & Kidneys, diabetes & Tea \\
\hline $\begin{array}{l}\text { Brassica smelledacea } \\
\mathrm{L} \text {. }\end{array}$ & $\mathrm{Col}$ & 2 & 0 & 2 & Indigestion, insomnia & $\begin{array}{l}\text { Placed under the pillow } \\
\text { belly and back }\end{array}$ \\
\hline Bromelia pinguin L. & Tim & 1 & 0 & 0 & Kidneys, gastritis & Tea, eaten \\
\hline $\begin{array}{l}\text { Brownea ariza } \\
\text { Benth. }\end{array}$ & Palo de Cruz & 2 & 2 & 0 & Bruises & Washing, tea \\
\hline $\begin{array}{l}\text { Bunchosia canescens } \\
\text { (Aiton) DC. }\end{array}$ & $\begin{array}{l}\text { Nanche } \\
\text { criollo/Nanche } \\
\text { de perro }\end{array}$ & 1 & 1 & 1 & Inflammation, diarrhea & Tea \\
\hline $\begin{array}{l}\text { Bursera ariensis } \\
\text { (Kunth) McVaugh \& } \\
\text { Rzed. }\end{array}$ & $\begin{array}{l}\text { Palo de Oro/ } \\
\text { Palo Dorado }\end{array}$ & 1 & 13 & 3 & Bones, fever, knees, heels, hips, fractures & $\begin{array}{l}\text { Applied to affected area, } \\
\text { patches, tea }\end{array}$ \\
\hline $\begin{array}{l}\text { Bursera bipinnata } \\
\text { (Moc. \& Sessé ex } \\
\text { DC.) Engl. }\end{array}$ & $\begin{array}{l}\text { Copal de } \\
\text { Piedra }\end{array}$ & 1 & 0 & 1 & Postpartum & Smoked \\
\hline $\begin{array}{l}\text { Bursera copallifera } \\
\text { (Sessé \& Moc. ex } \\
\text { DC.) Bullock }\end{array}$ & Copal & 1 & 4 & 0 & Cough, purify blood, fever & $\begin{array}{l}\text { Inhale steam, patches, } \\
\text { boiled }\end{array}$ \\
\hline $\begin{array}{l}\text { Bursera grandifolia } \\
\text { (Schltdl.) Engl. }\end{array}$ & Palo mulato & 1 & 1 & 2 & Wounds, bruises, purify blood & Boiled, smeared, washing \\
\hline $\begin{array}{l}\text { Byrsonima crassifolia } \\
\text { (L.) Kunth }\end{array}$ & Nanche & 1 & 0 & 1 & Indigestion & Tea \\
\hline $\begin{array}{l}\text { Calea zacatechichi } \\
\text { Schltdl. }\end{array}$ & $\begin{array}{l}\text { Prodigiosa/ } \\
\text { Zacatechichi/ } \\
\text { Amula }\end{array}$ & 1 & 20 & 27 & $\begin{array}{l}\text { Diabetes, anger, terror, stomachache, } \\
\text { menstrual cramps, diarrhea, cold, } \\
\text { diabetes }\end{array}$ & Tea, alcohol \\
\hline $\begin{array}{l}\text { Camellia sinensis (L.) } \\
\text { Kuntze }\end{array}$ & $\begin{array}{l}\text { Tea de la } \\
\text { india }\end{array}$ & 2 & 0 & 0 & Anger & Boiled \\
\hline Cannabis sativa $\mathrm{L}$. & Marihuana & 2 & 0 & 1 & Muscle pain & Alcohol \\
\hline $\begin{array}{l}\text { Capsicum annuum } \\
\text { L. }\end{array}$ & Chile & 1 & 0 & 1 & Aerophagia in children & Smoked \\
\hline Carica papaya L. & $\begin{array}{l}\text { Papaya/ } \\
\text { Papayo }\end{array}$ & 1 & 1 & 5 & $\begin{array}{l}\text { Scorpion sting, stomachache, dengue, } \\
\text { Zika }\end{array}$ & $\begin{array}{l}\text { Tea, baths, applied to } \\
\text { affected area }\end{array}$ \\
\hline $\begin{array}{l}\text { Carya illinoinensis } \\
\text { (Wangenh.) K.Koch }\end{array}$ & Nuez & 2 & 0 & 1 & Diabetes & Liquified \\
\hline $\begin{array}{l}\text { Cascabela ovata } \\
\text { (Cav.) Lippold }\end{array}$ & Ayoyote & 1 & 1 & 0 & Skin infections & Tea \\
\hline $\begin{array}{l}\text { Casimiroa edulis La } \\
\text { Llave }\end{array}$ & Zapote blanco & 1 & 0 & 4 & $\begin{array}{l}\text { High triglycerides, high blood pressure, } \\
\text { insomnia, cough }\end{array}$ & $\begin{array}{l}\text { Tea, placed under the } \\
\text { pillow }\end{array}$ \\
\hline $\begin{array}{l}\text { Cecropia obtusifolia } \\
\text { Bertol. }\end{array}$ & Guarumbo & 1 & 0 & 1 & Diabetes & Tea \\
\hline Ceiba pentandra (L.) & Pochote & 1 & 0 & 1 & Strenghten immune system & Tea \\
\hline
\end{tabular}


Table 7 All recorded plants and their uses (Continued)

\begin{tabular}{|c|c|c|c|c|c|c|}
\hline Species & $\begin{array}{l}\text { Common } \\
\text { name }\end{array}$ & $\begin{array}{l}\text { Origin (1: } \\
\text { native, 2: } \\
\text { introduced) }\end{array}$ & $\begin{array}{l}\text { Number } \\
\text { of } \\
\text { mentions } \\
\text { (ELC) }\end{array}$ & $\begin{array}{l}\text { Number } \\
\text { of } \\
\text { mentions } \\
\text { (TGO) }\end{array}$ & Use & Preparation methods \\
\hline \multicolumn{7}{|l|}{ Gaertn. } \\
\hline $\begin{array}{l}\text { Chamaemelum } \\
\text { nobile (L.) All. }\end{array}$ & Manzanilla & 2 & 0 & 54 & $\begin{array}{l}\text { Stomachache, eye irritation, flu, colic in } \\
\text { babies, fever, diarrhea, cough }\end{array}$ & Tea, drops, washing \\
\hline $\begin{array}{l}\text { Chamaesyce } \\
\text { umbellulata } \\
\text { (Engelm. ex Boiss.) } \\
\text { Millsp. }\end{array}$ & Hierbabuenilla & 2 & 0 & 0 & Bruises and inflammation & Tea \\
\hline $\begin{array}{l}\text { Chelidonium majus } \\
\text { L. }\end{array}$ & Celidonea & 2 & 0 & 2 & Skin rash, inflammation & $\begin{array}{l}\text { Baths, applied to affected } \\
\text { area }\end{array}$ \\
\hline $\begin{array}{l}\text { Chiranthodendron } \\
\text { pentadactylon } \\
\text { Larreat. }\end{array}$ & $\begin{array}{l}\text { Flor de } \\
\text { Manitas }\end{array}$ & 1 & 0 & 1 & Pain & Tea \\
\hline $\begin{array}{l}\text { Cinnamomum } \\
\text { verum J.Presl }\end{array}$ & Canela & 2 & 0 & 7 & Cough, diarrhea, vomit, stomachache & Tea \\
\hline $\begin{array}{l}\text { Cirsium ehrenbergii } \\
\text { Sch.Bip. }\end{array}$ & Cardo & 1 & 0 & 1 & Love potion & Alcohol \\
\hline $\begin{array}{l}\text { Cissus verticillata (L.) } \\
\text { Nicolson \& C.E.Jarvis }\end{array}$ & Tripa de Judas & 1 & 2 & 0 & Scorpion sting & Boiled \\
\hline $\begin{array}{l}\text { Citrus aurantiifolia } \\
\text { (Christm.) Swingle }\end{array}$ & $\begin{array}{l}\text { Lima/Lima } \\
\text { Chichona/ } \\
\text { Lima Real/Flor } \\
\text { de Azahar }\end{array}$ & 2 & 0 & 5 & High blood pressure, nerves & Tea, eaten, liquified \\
\hline $\begin{array}{l}\text { Citrus limon (L.) } \\
\text { Osbeck }\end{array}$ & $\begin{array}{l}\text { Limón/Flor de } \\
\text { Azahar }\end{array}$ & 2 & 1 & 16 & $\begin{array}{l}\text { Nerves, prostate, diarrhea, low blood } \\
\text { pressure, kidney stones, inflammation, flu, } \\
\text { diabetes, fever, Scorpion sting, cough, } \\
\text { chest pain, insomnia }\end{array}$ & $\begin{array}{l}\text { Tea, necklace, liquified, } \\
\text { juice, rinses, applied to } \\
\text { affected area, with milk }\end{array}$ \\
\hline $\begin{array}{l}\text { Citrus maxima } \\
\text { (Burm.) Merr. }\end{array}$ & Toronja & 2 & 0 & 1 & High triglycerides & Juice \\
\hline $\begin{array}{l}\text { Citrus reticulata } \\
\text { Blanco }\end{array}$ & Mandarina & 2 & 0 & 1 & Cough & Tea \\
\hline $\begin{array}{l}\text { Citrus sinensis (L.) } \\
\text { Osbeck }\end{array}$ & $\begin{array}{l}\text { Naranja/Flor } \\
\text { de Azahar }\end{array}$ & 2 & 1 & 3 & Postpartum, flu, cough, headache & Boiled, juice, baths \\
\hline $\begin{array}{l}\text { Cnidoscolus } \\
\text { aconitifolius (Mill.) } \\
\text { I.M.Johnst. }\end{array}$ & Chaya & 1 & 0 & 3 & Prostate, uric acid, kidneys & Tea, liquified \\
\hline $\begin{array}{l}\text { Cochlospermum } \\
\text { vitifolium (Willd.) } \\
\text { Spreng. }\end{array}$ & $\begin{array}{l}\text { Palo de } \\
\text { Pánico/Pánico }\end{array}$ & 1 & 4 & 0 & Diabetes, gastritis & Tea \\
\hline Cocos nucifera L. & Coco & 2 & 0 & 1 & Platelets & Tea \\
\hline Coffea arabica L. & Café & 2 & 0 & 1 & Dengue & Placed on soles with butter \\
\hline $\begin{array}{l}\text { Commelina zebrina } \\
\text { C.B.Clarke }\end{array}$ & $\begin{array}{l}\text { Hierba del } \\
\text { pollo/Hoja de } \\
\text { pollo }\end{array}$ & 1 & 0 & 7 & $\begin{array}{l}\text { Wounds, diabetes, dysentery, anemia, } \\
\text { kidneys }\end{array}$ & Tea, liquified \\
\hline $\begin{array}{l}\text { Conyza coronopifolia } \\
\text { Kunth }\end{array}$ & Gordolobo & 1 & 2 & 1 & Cough, bronchitis & Tea \\
\hline $\begin{array}{l}\text { Cordia boissieri } \\
\text { A.DC. }\end{array}$ & Anacahuite & 1 & 2 & 2 & Cough & Tea \\
\hline $\begin{array}{l}\text { Cordia morelosana } \\
\text { Standl. }\end{array}$ & Palo Prieto & 1 & 0 & 2 & Cough, cystitis & Tea \\
\hline $\begin{array}{l}\text { Coryphantha } \\
\text { elephantidens subsp. } \\
\text { bumamma } \\
\text { (Ehrenb.) Dicht \& } \\
\text { A.Lüthy * }\end{array}$ & Biznaga & 1 & 2 & 2 & Diabetes, pityriasis rosacea, kidneys & Tea, liquified, eaten \\
\hline
\end{tabular}


Table 7 All recorded plants and their uses (Continued)

\begin{tabular}{|c|c|c|c|c|c|c|}
\hline Species & $\begin{array}{l}\text { Common } \\
\text { name }\end{array}$ & $\begin{array}{l}\text { Origin (1: } \\
\text { native, 2: } \\
\text { introduced) }\end{array}$ & $\begin{array}{l}\text { Number } \\
\text { of } \\
\text { mentions } \\
\text { (ELC) }\end{array}$ & $\begin{array}{l}\text { Number } \\
\text { of } \\
\text { mentions } \\
\text { (TGO) }\end{array}$ & Use & Preparation methods \\
\hline $\begin{array}{l}\text { Costus spicatus } \\
\text { (Jacq.) Sw. }\end{array}$ & Caña & 1 & 0 & 1 & Kidneys & Tea \\
\hline $\begin{array}{l}\text { Crataegus mexicana } \\
\text { DC. }\end{array}$ & Tejocote & 1 & 0 & 1 & Cough & Tea \\
\hline $\begin{array}{l}\text { Crescentia alata } \\
\text { Kunth }\end{array}$ & Cuatecomate & 1 & 14 & 50 & $\begin{array}{l}\text { Cough, kidneys, asthma, bronchitis, } \\
\text { pneumonia, lungs, cancer, gastric ulcer, } \\
\text { earache }\end{array}$ & $\begin{array}{l}\text { Drops, tea, syrup, alcohol, } \\
\text { wine }\end{array}$ \\
\hline Croton niveus Jacq. & Copalzi & 1 & 1 & 0 & Purify blood, diabetes & Boiled \\
\hline Cucumis sativus $\mathrm{L}$. & Pepino & 2 & 0 & 1 & Wounds & Applied to affected area \\
\hline $\begin{array}{l}\text { Cucurbita moschata } \\
\text { Duchesne }\end{array}$ & Calabaza & 1 & 1 & 0 & Diarrhea & Tea \\
\hline $\begin{array}{l}\text { Cuminum cyminum } \\
\mathrm{L} \text {. }\end{array}$ & Comino & 2 & 0 & 4 & $\begin{array}{l}\text { Stomachache, bulging belly, vomiting, } \\
\text { diarrhea }\end{array}$ & Tea \\
\hline $\begin{array}{l}\text { Cunila lythrifolia } \\
\text { Benth. }\end{array}$ & Poleo & 1 & 0 & 3 & Flu, pain & Vaporizations, tea \\
\hline $\begin{array}{l}\text { Cuphea micropetala } \\
\text { Kunth }\end{array}$ & Taray & 1 & 0 & 1 & Kindeys & Tea \\
\hline $\begin{array}{l}\text { Cuscuta tinctoria } \\
\text { Mart. ex Engelm. }\end{array}$ & Chahuistle & 1 & 0 & 1 & Cold sores, sores & Applied to affected area \\
\hline $\begin{array}{l}\text { Cymbopogon } \\
\text { citratus (DC.) Stapf }\end{array}$ & $\begin{array}{l}\text { Tea de Caña/ } \\
\text { Zacatelimón }\end{array}$ & 2 & 0 & 3 & Nerves, blood pressure & Tea \\
\hline $\begin{array}{l}\text { Dalea alopecuroides } \\
\text { Willd. }\end{array}$ & Escoba & 1 & 0 & 2 & Vaginal bleeding & Tea \\
\hline Datura innoxia Mill. & Toloache & 1 & 1 & 0 & Swollen pimples, bruises & Tea \\
\hline $\begin{array}{l}\text { Diphysa americana } \\
\text { (Mill.) M.Sousa }\end{array}$ & Chicharronsillo & 1 & 1 & 0 & Fever, diarrhea & Tea \\
\hline $\begin{array}{l}\text { Dysphania } \\
\text { ambrosioides (L.) } \\
\text { Mosyakin \& } \\
\text { Clemants }\end{array}$ & Epazote & 1 & 1 & 10 & $\begin{array}{l}\text { Diarrhea, stomach parasites, menstrual } \\
\text { cramps, stomachache }\end{array}$ & Tea, eaten \\
\hline $\begin{array}{l}\text { Elytraria acaulis (L.f.) } \\
\text { Lindau }\end{array}$ & Viborilla & 2 & 3 & 0 & Snakebite or scorpion sting & Boiled, chewed \\
\hline Equisetum arvense $\mathrm{L}$. & $\begin{array}{l}\text { Cola de } \\
\text { caballo }\end{array}$ & 1 & 0 & 5 & Kidneys, wounds, cystitis & Tea \\
\hline $\begin{array}{l}\text { Eriobotrya japonica } \\
\text { (Thunb.) Lindl. }\end{array}$ & Níspero & 2 & 0 & 1 & Migraine & Tea \\
\hline $\begin{array}{l}\text { Eryngium } \\
\text { beecheyanum Hook. } \\
\& \text { Arn. }\end{array}$ & $\begin{array}{l}\text { Hierba del } \\
\text { sapo }\end{array}$ & 1 & 0 & 1 & Swollen feet & Tea \\
\hline $\begin{array}{l}\text { Erythrina americana } \\
\text { Mill. }\end{array}$ & Chompantle & 1 & 1 & 0 & Kidneys & Tea \\
\hline $\begin{array}{l}\text { Eucalyptus globulus } \\
\text { Labill. }\end{array}$ & Eucalipto & 2 & 1 & 7 & Flu, bronchitis & Tea, vaporizations \\
\hline $\begin{array}{l}\text { Euphorbia aaron- } \\
\text { rossii A.H.Holmgren } \\
\text { \& N.H.Holmgren }\end{array}$ & Istumeca & 1 & 0 & 1 & Fever & Applied to affected area \\
\hline $\begin{array}{l}\text { Euphorbia } \\
\text { tithymaloides L. }\end{array}$ & Zapatito & 1 & 0 & 2 & Buried spines & Applied to affected area \\
\hline $\begin{array}{l}\text { Eysenhardtia } \\
\text { polystachya (Ortega) } \\
\text { Sarg. }\end{array}$ & $\begin{array}{l}\text { Palo Dulce/ } \\
\text { Palo Azul }\end{array}$ & 1 & 15 & 20 & $\begin{array}{l}\text { Kidneys, cystitis, diabetes, burning feet, } \\
\text { gastritis }\end{array}$ & Tea, washing, \\
\hline Ficus carica L. & Higo & 2 & 0 & 3 & High triglycerides, diabetes, wounds & Tea \\
\hline
\end{tabular}


Table 7 All recorded plants and their uses (Continued)

\begin{tabular}{|c|c|c|c|c|c|c|}
\hline Species & $\begin{array}{l}\text { Common } \\
\text { name }\end{array}$ & $\begin{array}{l}\text { Origin (1: } \\
\text { native, } 2: \\
\text { introduced) }\end{array}$ & $\begin{array}{l}\text { Number } \\
\text { of } \\
\text { mentions } \\
\text { (ELC) }\end{array}$ & $\begin{array}{l}\text { Number } \\
\text { of } \\
\text { mentions } \\
\text { (TGO) }\end{array}$ & Use & Preparation methods \\
\hline Ficus sp. & Amate & 1 & 0 & 2 & Fever & Placed on feet \\
\hline $\begin{array}{l}\text { Foeniculum vulgare } \\
\text { Mill. }\end{array}$ & Hinojo & 2 & 0 & 1 & Stomachache, diarrhea & Tea \\
\hline $\begin{array}{l}\text { Guadua amplexifolia } \\
\text { J.Presl }\end{array}$ & Otate & 1 & 0 & 1 & Gumboil & Tea \\
\hline $\begin{array}{l}\text { Guazuma ulmifolia } \\
\text { Lam. }\end{array}$ & $\begin{array}{l}\text { Caulote/ } \\
\text { Cuauhulote }\end{array}$ & 1 & 0 & 5 & $\begin{array}{l}\text { Red stains in babies, kidneys, colic in } \\
\text { babies }\end{array}$ & Baths, washing, infusion \\
\hline $\begin{array}{l}\text { Haematoxylum } \\
\text { brasiletto H.Karst. }\end{array}$ & Palo de Brasil & 1 & 14 & 15 & $\begin{array}{l}\text { Prostate, kidneys, cystitis, herpes, clean } \\
\text { face, fever, diabetes, lungs, blood } \\
\text { pressure }\end{array}$ & Tea, rinses \\
\hline $\begin{array}{l}\text { Helianthemum } \\
\text { glomeratum (Lag.) } \\
\text { Lag. ex Dunal }\end{array}$ & Santa Martha & 1 & 0 & 1 & Muscle ache & Alcohol \\
\hline $\begin{array}{l}\text { Heliocarpus } \\
\text { americanus L. }\end{array}$ & Clanguilagua & 1 & 0 & 2 & Cystitis, Scorpion sting & Tea, eaten \\
\hline $\begin{array}{l}\text { Heteropterys } \\
\text { brachiata (L.) DC. }\end{array}$ & Margarita & 1 & 3 & 3 & $\begin{array}{l}\text { Skin irritation, purify blood, cough, } \\
\text { kidneys }\end{array}$ & Tea, baths, infusion \\
\hline $\begin{array}{l}\text { Heterotheca } \\
\text { inuloides Cass. }\end{array}$ & Árnica & 1 & 6 & 13 & $\begin{array}{l}\text { Sprains, wounds, gastritis, kidney stones, } \\
\text { pain, bruises, inflammation, liver }\end{array}$ & $\begin{array}{l}\text { Tea, plater, applied to } \\
\text { affected area, washing, } \\
\text { smeared, poultice }\end{array}$ \\
\hline Hibiscus sabdariffa $\mathrm{L}$. & Jamaica & 2 & 0 & 1 & Kidneys & Tea \\
\hline $\begin{array}{l}\text { Hintonia latiflora } \\
\text { (Sessé \& Moc. ex } \\
\text { DC.) Bullock }\end{array}$ & Quina & 1 & 1 & 2 & Bile, wounds, flu, purify blood & Tea \\
\hline $\begin{array}{l}\text { Hippocratea excelsa } \\
\text { Kunth }\end{array}$ & $\begin{array}{l}\text { Ixcate/ } \\
\text { Cancerina }\end{array}$ & 1 & 3 & 7 & $\begin{array}{l}\text { Wounds, gastritis, yeast infections, cold } \\
\text { sores }\end{array}$ & $\begin{array}{l}\text { Tea, ground, washing, } \\
\text { applied to affected area }\end{array}$ \\
\hline $\begin{array}{l}\text { Illicium verum } \\
\text { Hook.f. }\end{array}$ & $\begin{array}{l}\text { Anís/Anís de } \\
\text { Estrella }\end{array}$ & 2 & 0 & 3 & Stomachache, vomiting, diarrhea & Tea \\
\hline Inga vera Willd. & Jinicuil & 1 & 1 & 0 & Stress & Tea \\
\hline $\begin{array}{l}\text { Ipomoea } \\
\text { arborescens (Humb. } \\
\text { \& Bonpl. ex Willd.) } \\
\text { G. Don }\end{array}$ & $\begin{array}{l}\text { Palo Blanco/ } \\
\text { Cazahuate }\end{array}$ & 1 & 1 & 2 & Cancer, scorpion sting & Tea \\
\hline $\begin{array}{l}\text { Ipomoea murucoides } \\
\text { Roem. \& Schult. }\end{array}$ & $\begin{array}{l}\text { Cazahuate } \\
\text { amarillo }\end{array}$ & 1 & 1 & 1 & Throat inflammation, cough & $\begin{array}{l}\text { Tea, applied to affected } \\
\text { area }\end{array}$ \\
\hline $\begin{array}{l}\text { Justicia spicigera } \\
\text { Schltdl. }\end{array}$ & Muicle & 1 & 2 & 15 & $\begin{array}{l}\text { Kidneys, rash, varicella, red blood cells, } \\
\text { circulation, migraine, cystitis, allergies }\end{array}$ & Baths, tea, \\
\hline $\begin{array}{l}\text { Lasiacis nigra } \\
\text { Davidse }\end{array}$ & Carricillo & 2 & 0 & 3 & Kidneys, gallbladder & Liquified, tea \\
\hline $\begin{array}{l}\text { Lemaireocereus } \\
\text { hollianus (F.A.C. } \\
\text { Weber) Britton \& } \\
\text { Rose }\end{array}$ & Calehuale & 1 & 1 & 0 & Diarrhea & Tea \\
\hline $\begin{array}{l}\text { Leucaena esculenta } \\
\text { (DC.) Benth. }\end{array}$ & $\begin{array}{l}\text { Guaje } \\
\text { colorado }\end{array}$ & 1 & 0 & 1 & Cold sore & Applied to affected area \\
\hline Lippia dulcis Trevir. & Hierba Dulce & 1 & 1 & 0 & Head ache & Boiled \\
\hline $\begin{array}{l}\text { Lippia graveolens } \\
\text { Kunth }\end{array}$ & Orégano & 1 & 0 & 3 & Stomachache, menstrual cramps & Tea \\
\hline $\begin{array}{l}\text { Loeselia mexicana } \\
\text { (Lam.) Brand }\end{array}$ & Espinosilla & 1 & 1 & 0 & Fever & Tea \\
\hline $\begin{array}{l}\text { Ludwigia octovalvis } \\
\text { (Jacq.) P.H.Raven }\end{array}$ & Clavillo & 1 & 0 & 1 & High blood pressure & Tea \\
\hline
\end{tabular}


Table 7 All recorded plants and their uses (Continued)

\begin{tabular}{|c|c|c|c|c|c|c|}
\hline Species & $\begin{array}{l}\text { Common } \\
\text { name }\end{array}$ & $\begin{array}{l}\text { Origin (1: } \\
\text { native, 2: } \\
\text { introduced) }\end{array}$ & $\begin{array}{l}\text { Number } \\
\text { of } \\
\text { mentions } \\
\text { (ELC) }\end{array}$ & $\begin{array}{l}\text { Number } \\
\text { of } \\
\text { mentions } \\
\text { (TGO) }\end{array}$ & Use & Preparation methods \\
\hline $\begin{array}{l}\text { Malus domestica } \\
\text { Borkh. }\end{array}$ & Manzana & 2 & 0 & 1 & Diabetes & Liquified \\
\hline Malva parviflora $\mathrm{L}$. & Malva & 2 & 0 & 0 & Inflammation & Tea \\
\hline $\begin{array}{l}\text { Malvaviscus } \\
\text { arboreus Cav. }\end{array}$ & Monacillo & 1 & 0 & 1 & Stomachache & Tea \\
\hline Mangifera indica $\mathrm{L}$. & Mango & 2 & 0 & 2 & Diabetes, cough & Tea \\
\hline $\begin{array}{l}\text { Marginatocereus } \\
\text { marginatus (DC.) } \\
\text { Backeb. }\end{array}$ & Orégano & 1 & 1 & 1 & Scorpion sting & Applied to affected area \\
\hline $\begin{array}{l}\text { Marina nutans (Cav.) } \\
\text { Barneby }\end{array}$ & Escoba roja & 1 & 0 & 0 & Vaginal bleeding, fidelity & Tea \\
\hline $\begin{array}{l}\text { Marrubium vulgare } \\
\mathrm{L} \text {. }\end{array}$ & Manrubio & 2 & 3 & 0 & Diarrhea & Boiled \\
\hline $\begin{array}{l}\text { Marsdenia lanata } \\
\text { (Paul G. Wilson) } \\
\text { W.D. Stevens }\end{array}$ & $\begin{array}{l}\text { Caxancapatli } \\
\text { blanco }\end{array}$ & 1 & 0 & 1 & Postpartum & Baths \\
\hline Melia azedarach L. & Paraíso & 2 & 0 & 1 & Indigestion & Tea \\
\hline $\begin{array}{l}\text { Mentha canadensis } \\
\mathrm{L} \text {. }\end{array}$ & Hierba buena & 2 & 12 & 42 & $\begin{array}{l}\text { Stomachache, vomit, menstrual cramps, } \\
\text { diarrhea, toothache, stress, bad breath, } \\
\text { bruises }\end{array}$ & $\begin{array}{l}\text { Tea, foments, infusion, } \\
\text { chewed }\end{array}$ \\
\hline Mentha spicata L. & Menta & 2 & 0 & 1 & Stomachache & Tea \\
\hline $\begin{array}{l}\text { Microlobius foetidus } \\
\text { (Jacq.) M.Sousa \& } \\
\text { G.Andrade }\end{array}$ & Hediondillo & 1 & 0 & 1 & Rash in children & Rub over body \\
\hline $\begin{array}{l}\text { Mimosa affinis } \\
\text { Robinson }\end{array}$ & Dormilona & 1 & 0 & 0 & Vaginal bleeding & Tea \\
\hline $\begin{array}{l}\text { Mimosa albida } \\
\text { Willd. }\end{array}$ & Uña de Gato & 1 & 0 & 2 & Kidneys, prostate & Tea \\
\hline $\begin{array}{l}\text { Mimosa benthamii } \\
\text { J.F.Macbr. }\end{array}$ & Tecolhuixtle & 1 & 1 & 0 & Wounds & Tea \\
\hline $\begin{array}{l}\text { Montanoa } \\
\text { tomentosa Cerv. }\end{array}$ & $\begin{array}{l}\text { Vara de } \\
\text { Cuilota }\end{array}$ & 1 & 0 & 1 & Bruises & Washing \\
\hline Morinda citrifolia $\mathrm{L}$. & Noni & 2 & 0 & 2 & High triglycerides, diabetes & Tea, liquified \\
\hline $\begin{array}{l}\text { Moringa oleifera } \\
\text { Lam. }\end{array}$ & Moringa & 2 & 1 & 26 & $\begin{array}{l}\text { Diabetes, menstrual cramps, dizziness, } \\
\text { knee pain, kidneys, cancer, high } \\
\text { triglycerides, energy }\end{array}$ & $\begin{array}{l}\text { Tea, liquified, eaten, } \\
\text { chewed }\end{array}$ \\
\hline $\begin{array}{l}\text { Moussonia } \\
\text { deppeana (Schltdl. \& } \\
\text { Cham.) Klotzsch ex } \\
\text { Hanst. }\end{array}$ & Cacahuetillo & 1 & 1 & 0 & Diarrhea & Tea \\
\hline $\begin{array}{l}\text { Musa balbisiana } \\
\text { Colla }\end{array}$ & $\begin{array}{l}\text { Platano } \\
\text { macho }\end{array}$ & 2 & 1 & 0 & Diabetes, gastritis & Tea \\
\hline $\begin{array}{l}\text { Myristica fragrans } \\
\text { Houtt. }\end{array}$ & Nuez Moscada & 2 & 0 & 4 & $\begin{array}{l}\text { Lungs, anger, dizziness, blood pressure, } \\
\text { postpartum }\end{array}$ & $\begin{array}{l}\text { Wine, placed under tongue } \\
\text { or area with pain, smoked }\end{array}$ \\
\hline $\begin{array}{l}\text { Myroxylon } \\
\text { balsamum (L.) } \\
\text { Harms }\end{array}$ & $\begin{array}{l}\text { Guayacán } \\
\text { amarillo }\end{array}$ & 2 & 4 & 0 & Anger & Boiled \\
\hline $\begin{array}{l}\text { Nicotiana glauca } \\
\text { Graham }\end{array}$ & $\begin{array}{l}\text { Hojas de } \\
\text { gigante }\end{array}$ & 1 & 0 & 1 & Toothache & Smeared \\
\hline $\begin{array}{l}\text { Nicotiana tabacum } \\
\text { L. }\end{array}$ & Tabaco & 1 & 0 & 2 & Postpartum, fever, chills & $\begin{array}{l}\text { Baths, applied to affected } \\
\text { area }\end{array}$ \\
\hline Nissolia fruticosa & Manea de & 1 & 0 & 1 & Kidneys & Tea \\
\hline
\end{tabular}


Table 7 All recorded plants and their uses (Continued)

\begin{tabular}{|c|c|c|c|c|c|c|}
\hline Species & $\begin{array}{l}\text { Common } \\
\text { name }\end{array}$ & $\begin{array}{l}\text { Origin (1: } \\
\text { native, 2: } \\
\text { introduced) }\end{array}$ & $\begin{array}{l}\text { Number } \\
\text { of } \\
\text { mentions } \\
\text { (ELC) }\end{array}$ & $\begin{array}{l}\text { Number } \\
\text { of } \\
\text { mentions } \\
\text { (TGO) }\end{array}$ & Use & Preparation methods \\
\hline Jacq. & toro & & & & & \\
\hline $\begin{array}{l}\text { Ocimum basilicum } \\
\text { L. }\end{array}$ & Albahaca & 2 & 3 & 10 & $\begin{array}{l}\text { Bad air, cold, cough, inflammation, } \\
\text { stomachache, earache, eye cataracts }\end{array}$ & $\begin{array}{l}\text { Baths, inhale steam, tea, } \\
\text { applied to affected area, } \\
\text { placed in eyes, smeared }\end{array}$ \\
\hline $\begin{array}{l}\text { Oenothera rosea } \\
\text { L'Hér. ex Aiton }\end{array}$ & $\begin{array}{l}\text { Hierba del } \\
\text { golpe }\end{array}$ & 1 & 4 & 6 & $\begin{array}{l}\text { Bruises, muscle aches, gastric ulcer, } \\
\text { sprains, inflammation }\end{array}$ & $\begin{array}{l}\text { Applied to affected area, } \\
\text { smeared, foments, tea, } \\
\text { washing, plater }\end{array}$ \\
\hline $\begin{array}{l}\text { Opuntia atropes } \\
\text { Rose }\end{array}$ & Nopal & 1 & 1 & 2 & Inflammation, diabetes, kidneys & Tea, liquified \\
\hline $\begin{array}{l}\text { Parmentiera } \\
\text { aculeata (Kunth) } \\
\text { Seem. }\end{array}$ & Cuajilote & 1 & 0 & 2 & Kidneys, earache & Eaten, drops, tea \\
\hline $\begin{array}{l}\text { Parthenium } \\
\text { hysterophorus L. }\end{array}$ & Cola de zorra & 1 & 2 & 0 & Anger & Tea \\
\hline $\begin{array}{l}\text { Passiflora edulis } \\
\text { Sims }\end{array}$ & Maracuyá & 2 & 0 & 26 & $\begin{array}{l}\text { Cough, dengue, platelets, diabetes, blood } \\
\text { pressure }\end{array}$ & Tea, syrup, juice \\
\hline $\begin{array}{l}\text { Peperomia } \\
\text { granulosa Trel. }\end{array}$ & Gordoncillo & 1 & 1 & 0 & Bone fractures & Tea \\
\hline $\begin{array}{l}\text { Persea americana } \\
\text { Mill. }\end{array}$ & Aguacate & 1 & 0 & 1 & Menstrual cramps & Tea \\
\hline $\begin{array}{l}\text { Persea liebmannii } \\
\text { Mez }\end{array}$ & Aguacatillo & 1 & 1 & 0 & Tapeworms & Tea \\
\hline $\begin{array}{l}\text { Phalaris canariensis } \\
\text { L. }\end{array}$ & Alpiste & 2 & 0 & 3 & Diabetes, blood pressure & $\begin{array}{l}\text { Tea, savor, applied to } \\
\text { affected area, massage, } \\
\text { baths }\end{array}$ \\
\hline Physalis pubescens L. & Tomate & 1 & 0 & 7 & $\begin{array}{l}\text { Tonsillitis, indigestion, vomit, postpartum, } \\
\text { narrow palate }\end{array}$ & Poultice \\
\hline $\begin{array}{l}\text { Pilea pubescens } \\
\text { Liebm. }\end{array}$ & Chichicastle & 1 & 0 & 1 & Skin allergies & Baths \\
\hline $\begin{array}{l}\text { Pinus leiophylla } \\
\text { Schiede ex Schltdl. } \\
\& \text { Cham. }\end{array}$ & Ocote & 1 & 0 & 1 & Cough & Tea \\
\hline Piper auritum Kunth & Hoja santa & 1 & 0 & 1 & Menstrual cramps & Tea \\
\hline $\begin{array}{l}\text { Piper leucophyllum } \\
\text { (Miq.) C. DC. }\end{array}$ & Cordoncillo & 1 & 0 & 1 & Purify children & Rub over body \\
\hline $\begin{array}{l}\text { Pithecellobium dulce } \\
\text { (Roxb.) Benth. }\end{array}$ & Guamuchil & 1 & 1 & 1 & Cystitis & Tea \\
\hline Pithecellobium sp. & $\begin{array}{l}\text { Guamuchil } \\
\text { morado }\end{array}$ & 1 & 0 & 1 & Wounds & Washing \\
\hline $\begin{array}{l}\text { Plectranthus } \\
\text { hadiensis (Forssk.) } \\
\text { Schweinf. ex } \\
\text { Sprenger }\end{array}$ & $\begin{array}{l}\text { Hierba de } \\
\text { Vaporub/ } \\
\text { Alcanfor }\end{array}$ & 2 & 0 & 3 & Cold, wounds, cough & Smeared, infusion, tea \\
\hline $\begin{array}{l}\text { Polygonum aviculare } \\
\text { L. }\end{array}$ & $\begin{array}{l}\text { Lengua de } \\
\text { pajaro }\end{array}$ & 1 & 0 & 1 & Cystitis & Tea \\
\hline $\begin{array}{l}\text { Porophyllum } \\
\text { ruderale (Jacq.) Cass. }\end{array}$ & $\begin{array}{l}\text { Papalo de } \\
\text { venado }\end{array}$ & 1 & 2 & 0 & Wounds & $\begin{array}{l}\text { Washing, place dried and } \\
\text { ground on area with pain, } \\
\text { tea }\end{array}$ \\
\hline $\begin{array}{l}\text { Prosopis juliflora } \\
\text { (Sw.) DC. }\end{array}$ & $\begin{array}{l}\text { Bejuco de } \\
\text { Mezquite }\end{array}$ & 1 & 0 & 0 & Kidneys & Tea \\
\hline $\begin{array}{l}\text { Prosopis laevigata } \\
\text { (Willd.) M.C.Johnst. }\end{array}$ & Mezquite & 1 & 1 & 0 & Liver & Boiled \\
\hline
\end{tabular}


Table 7 All recorded plants and their uses (Continued)

\begin{tabular}{|c|c|c|c|c|c|c|}
\hline Species & $\begin{array}{l}\text { Common } \\
\text { name }\end{array}$ & $\begin{array}{l}\text { Origin (1: } \\
\text { native, 2: } \\
\text { introduced) }\end{array}$ & $\begin{array}{l}\text { Number } \\
\text { of } \\
\text { mentions } \\
\text { (ELC) }\end{array}$ & $\begin{array}{l}\text { Number } \\
\text { of } \\
\text { mentions } \\
\text { (TGO) }\end{array}$ & Use & Preparation methods \\
\hline Psidium guajava $\mathrm{L}$. & Guayabo & 1 & 1 & 45 & $\begin{array}{l}\text { Hangover, stomachache, diarrhea, } \\
\text { vomiting, gastritis, colic, cough }\end{array}$ & Tea \\
\hline $\begin{array}{l}\text { Psittacanthus } \\
\text { calyculatus (DC.) } \\
\text { G.Don }\end{array}$ & $\begin{array}{l}\text { Injerto de } \\
\text { Huizache }\end{array}$ & 1 & 0 & 2 & Kidneys & Tea \\
\hline Punica granatum L. & Granada & 2 & 0 & 6 & $\begin{array}{l}\text { Cough, diarrhea, cancer, dysentery, } \\
\text { thrush, cold sores, wounds }\end{array}$ & $\begin{array}{l}\text { Tea, place dried and } \\
\text { ground on area with pain, } \\
\text { eaten, juice }\end{array}$ \\
\hline $\begin{array}{l}\text { Quercus castanea } \\
\text { Née }\end{array}$ & $\begin{array}{l}\text { Encino/ } \\
\text { Encinillo/ } \\
\text { Ahuatzitzin }\end{array}$ & 1 & 2 & 0 & Cough & Tea \\
\hline $\begin{array}{l}\text { Randia echinocarpa } \\
\text { Moc. \& Sessé ex DC. }\end{array}$ & $\begin{array}{l}\text { Granjel/ } \\
\text { Granjel manso }\end{array}$ & 1 & 9 & 3 & Kidneys, wounds, cystitis & Tea, washing, eaten \\
\hline $\begin{array}{l}\text { Rauvolfia tetraphylla } \\
\text { L. }\end{array}$ & $\begin{array}{l}\text { Tlanelpolo/ } \\
\text { Tlalnenelpol }\end{array}$ & 1 & 0 & 5 & $\begin{array}{l}\text { Postpartum, sore feet, diabetes, dengue, } \\
\text { muscle ache, typhoid, fever }\end{array}$ & Baths, tea, alcohol \\
\hline $\begin{array}{l}\text { Rhamnus } \\
\text { humboldtiana Willd. } \\
\text { ex Schult. }\end{array}$ & Coyotillo & 1 & 1 & 0 & Toothache & Chew leaves \\
\hline Ricinus communis $\mathrm{L}$. & $\begin{array}{l}\text { Higuerilla/ } \\
\text { Higuerillo }\end{array}$ & 2 & 2 & 12 & Indigestion, fever, stomachache & $\begin{array}{l}\text { Applied to affected area } \\
\text { and feet }\end{array}$ \\
\hline Rosa gallica L. & $\begin{array}{l}\text { Rosa de } \\
\text { Castilla }\end{array}$ & 2 & 0 & 1 & Colic in babies & Baths \\
\hline $\begin{array}{l}\text { Rosmarinus } \\
\text { officinalis L. }\end{array}$ & Romero & 2 & 0 & 2 & Stomachache, diabetes & Tea \\
\hline $\begin{array}{l}\text { Ruellia megasphaera } \\
\text { Lindau }\end{array}$ & Tea negro & 2 & 1 & 1 & Stomachache, vomiting, diarrhea & Tea \\
\hline Ruta chalepensis $\mathrm{L}$. & Ruda & 1 & 4 & 21 & $\begin{array}{l}\text { Bad air, indigestion, stomachache, } \\
\text { witchcraft, headache, menstrual cramps, } \\
\text { earache, dizziness, postpartum, anger }\end{array}$ & $\begin{array}{l}\text { Baths, inhale steam, tea, } \\
\text { rubbed over body, } \\
\text { smeared, drops, with milk }\end{array}$ \\
\hline $\begin{array}{l}\text { Sambucus } \\
\text { canadensis L. }\end{array}$ & Saúco & 1 & 0 & 1 & Cough & Tea \\
\hline $\begin{array}{l}\text { Sanvitalia } \\
\text { procumbens Lam. }\end{array}$ & Ojo de Gallo & 1 & 1 & 2 & Cystitis, kidneys & Tea \\
\hline Schinus molle L. & Pirul & 2 & 0 & 2 & Witchcraft, cold & Rubbed on body, tea \\
\hline $\begin{array}{l}\text { Sechium edule } \\
\text { (Jacq.) Sw. }\end{array}$ & Chayote & 1 & 0 & 1 & High blood pressure & Tea \\
\hline $\begin{array}{l}\text { Sedum frutescens } \\
\text { Rose }\end{array}$ & Siempreviva & 1 & 0 & 7 & Scorpion sting, eye web, irritated eyes & Drops, chewed, washing \\
\hline $\begin{array}{l}\text { Sedum } \\
\text { glaucophyllum R.T. } \\
\text { Clausen }\end{array}$ & Sin Vergüenza & 1 & 0 & 1 & Gumboil & Placed on cheeks \\
\hline $\begin{array}{l}\text { Selaginella } \\
\text { lepidophylla (Hook. } \\
\text { \& Grev.) Spring }\end{array}$ & $\begin{array}{l}\text { Doradilla/Flor } \\
\text { de Peña }\end{array}$ & 1 & 3 & 6 & Kidneys, ovary problems, wounds, lungs & Tea \\
\hline Senecio salignus DC. & Jarilla & 1 & 0 & 2 & Bad air, muscle ache & Rubbed over body, alcohol \\
\hline $\begin{array}{l}\text { Senna hirsuta (L.) } \\
\text { H.S.Irwin \& Barneby }\end{array}$ & Jehuite & 1 & 1 & 0 & Headache & Tea \\
\hline $\begin{array}{l}\text { Senna skinneri } \\
\text { (Benth.) H.S.Irwin \& } \\
\text { Barneby }\end{array}$ & Paraca & 1 & 6 & 6 & $\begin{array}{l}\text { Diarrhea, stomachache, indigestion, } \\
\text { kidneys, wounds, gastritis }\end{array}$ & Tea, washing \\
\hline $\begin{array}{l}\text { Senna spectabilis } \\
\text { (DC.) H.S.Irwin \& } \\
\text { Barneby }\end{array}$ & Candelillo & 1 & 1 & 0 & Ear ache & Drops \\
\hline
\end{tabular}


Table 7 All recorded plants and their uses (Continued)

\begin{tabular}{|c|c|c|c|c|c|c|}
\hline Species & $\begin{array}{l}\text { Common } \\
\text { name }\end{array}$ & $\begin{array}{l}\text { Origin (1: } \\
\text { native, } 2: \\
\text { introduced) }\end{array}$ & $\begin{array}{l}\text { Number } \\
\text { of } \\
\text { mentions } \\
\text { (ELC) }\end{array}$ & $\begin{array}{l}\text { Number } \\
\text { of } \\
\text { mentions } \\
\text { (TGO) }\end{array}$ & Use & Preparation methods \\
\hline $\begin{array}{l}\text { Serjania schiedeana } \\
\text { Schltdl. }\end{array}$ & $\begin{array}{l}\text { Palo de Tres } \\
\text { Costillas }\end{array}$ & 1 & 13 & 10 & $\begin{array}{l}\text { Prostate, kidneys, purify blood, bruises, } \\
\text { lungs, burning feet, diarrhea, } \\
\text { stomachache, inflammation, }\end{array}$ & Tea \\
\hline $\begin{array}{l}\text { Simira mexicana } \\
\text { (Bullock) Steyerm. }\end{array}$ & Quina Roja & 1 & 0 & 1 & Purify blood & Tea \\
\hline $\begin{array}{l}\text { Solanum } \\
\text { lycopersicum L. }\end{array}$ & Jitomate & 2 & 0 & 3 & Fever, diabetes, gums & $\begin{array}{l}\text { Tea, liquified, placed on } \\
\text { feet and belly }\end{array}$ \\
\hline $\begin{array}{l}\text { Solanum } \\
\text { marginatum L. f. }\end{array}$ & Sacamanteca & 1 & 0 & 1 & Cancer & Tea \\
\hline $\begin{array}{l}\text { Solanum nigrescens } \\
\text { M. Martens \& } \\
\text { Galeotti }\end{array}$ & Hierba Mora & 1 & 1 & 0 & Anger & Tea \\
\hline $\begin{array}{l}\text { Solanum tuberosum } \\
\mathrm{L} \text {. }\end{array}$ & Papa & 2 & 0 & 1 & Uric acid & Liquified \\
\hline $\begin{array}{l}\text { Spinacia } \\
\text { smelledacea L. }\end{array}$ & Espinaca & 2 & 0 & 1 & Diabetes & Liquified \\
\hline Spondias mombin L. & Ciruelo & 1 & 0 & 1 & Bruxism & Chewed \\
\hline $\begin{array}{l}\text { Stenocereus } \\
\text { queretaroensis } \\
\text { (F.A.C.Weber ex } \\
\text { Mathes.) Buxb. }\end{array}$ & Pitahaya roja & 1 & 0 & 1 & Cancer & Tea \\
\hline $\begin{array}{l}\text { Stevia rebaudiana } \\
\text { (Bertoni) Bertoni }\end{array}$ & Estevia & 2 & 0 & 1 & Diabetes & Tea \\
\hline $\begin{array}{l}\text { Swietenia } \\
\text { macrophylla King }\end{array}$ & Zopilote & 1 & 0 & 3 & Diabetes & Tea, chewed \\
\hline $\begin{array}{l}\text { Syzygium } \\
\text { aromaticum (L.) } \\
\text { Merr. \& L.M.Perry }\end{array}$ & Clavo & 2 & 0 & 2 & Toothache & Chewed \\
\hline Tagetes erecta $\mathrm{L}$. & Cempasúchil & 1 & 1 & 1 & Stomachache, anger & Tea \\
\hline Tagetes lucida Cav. & Pericón & 1 & 3 & 11 & $\begin{array}{l}\text { Stomachache, cough, postpartum, } \\
\text { rheumatism, dengue, menstrual cramps, } \\
\text { foot pain, wounds, anger }\end{array}$ & Tea, baths, inhaled steam \\
\hline Tamarindus indica $\mathrm{L}$. & Tamarindo & 2 & 0 & 2 & Constipation, parasites & Tea \\
\hline $\begin{array}{l}\text { Taraxacum officinale } \\
\text { (Ledeb.) Schinz ex } \\
\text { Thell. }\end{array}$ & $\begin{array}{l}\text { Diente de } \\
\text { León }\end{array}$ & 2 & 0 & 2 & Varicose vains, cancer & Tea \\
\hline $\begin{array}{l}\text { Tecoma stans (L.) } \\
\text { Juss. ex Kunth }\end{array}$ & $\begin{array}{l}\text { Tronadora/ } \\
\text { Histoncle }\end{array}$ & 1 & 0 & 1 & Diabetes & Tea \\
\hline Thymus vulgaris $\mathrm{L}$. & Tomillo & 2 & 1 & 0 & Stomachache & Tea \\
\hline $\begin{array}{l}\text { Tilia mexicana } \\
\text { Schltdl. }\end{array}$ & Tila & 1 & 0 & 3 & Nerves & Tea \\
\hline $\begin{array}{l}\text { Tournefortia } \\
\text { hirsutissima L. }\end{array}$ & $\begin{array}{l}\text { Hierba } \\
\text { rasposa/ } \\
\text { Tlalchichinole }\end{array}$ & 1 & 12 & 26 & $\begin{array}{l}\text { Gastritis, diaper rash, wounds, kidneys, } \\
\text { hand ache, stomachache, gastric ulcer, } \\
\text { postpartum, liver, colic, cystitis }\end{array}$ & $\begin{array}{l}\text { Tea, applied to affected } \\
\text { area, infusion, washing, } \\
\text { liquified, poultice, ground, } \\
\text { chewed }\end{array}$ \\
\hline $\begin{array}{l}\text { Tradescantia } \\
\text { spathacea Sw. }\end{array}$ & $\begin{array}{l}\text { Maguey } \\
\text { morado/ } \\
\text { Barquita }\end{array}$ & 1 & 2 & 1 & Waist ache & Tea \\
\hline $\begin{array}{l}\text { Vaccinium } \\
\text { erythrocarpum } \\
\text { Michx. }\end{array}$ & Arándano & 2 & 0 & 1 & Diabetes & Liquified \\
\hline $\begin{array}{l}\text { Verbesina } \\
\text { abscondita Klatt }\end{array}$ & Capitaneja & 1 & 0 & 2 & Kidneys, muscle ache & Tea, alcohol \\
\hline
\end{tabular}


Table 7 All recorded plants and their uses (Continued)

\begin{tabular}{lllllll}
\hline Species & $\begin{array}{l}\text { Common } \\
\text { name }\end{array}$ & $\begin{array}{l}\text { Origin (1: } \\
\text { native, 2: } \\
\text { introduced) }\end{array}$ & $\begin{array}{l}\text { Number } \\
\text { of } \\
\text { mentions } \\
\text { (ELC) }\end{array}$ & $\begin{array}{l}\text { Number } \\
\text { of } \\
\text { mentions } \\
\text { (TGO) }\end{array}$ & Use & Preparation methods \\
\hline $\begin{array}{l}\text { Verbesina crocata } \\
\text { (Cav.) Less. }\end{array}$ & Capitaneja & 1 & 1 & 1 & Kidneys & Tea \\
Vitex hemsleyi Briq. & Querengue & 1 & 1 & 0 & Kidneys & Tea \\
Vitex mollis Kunth & Coyontomate & 1 & 1 & 1 & Cystitis, purify blood & Tea \\
Vitis vinifera L. & Pasas & 2 & 0 & 1 & High blood pressure & Tea \\
Waltheria indica L. & $\begin{array}{l}\text { Cuaulotillo/ } \\
\text { Tapacola/ }\end{array}$ & 1 & 2 & 12 & Diarrhea, stomachache & Tea \\
Zea mays L. & $\begin{array}{l}\text { Tapaculo } \\
\text { Elote }\end{array}$ & 1 & 1 & 4 & Kidneys, cystitis, lungs & Tea, applied to affected \\
Zornia thymifolia & $\begin{array}{l}\text { Hierba de la } \\
\text { Kunth }\end{array}$ & 1 & 1 & 1 & Cold sore, snake bytes & area \\
\hline
\end{tabular}

This dynamic of exchange of medicinal resources through the fair in TGO may also explain the increased use of introduced species and purchase (rather than gathering) of medicinal plants) in this community. As a consequence, in the more urbanized community of TGO, the number of introduced and domesticated species was a significant component of the medicinal plants known by the interviewees. In contrast, in the less urbanized community of ELC, native TDF plants and wild plants were more frequently mentioned and used. This is consistent with research by Blair that mentions that in moderately urbanized contexts, there is increased presence of useful plants, though these tend to be introduced [80]. In addition, a number of authors have proposed that in contemporary tropical pharmacopeias, people prefer introduced species to complement their therapeutic repertoir $[81,82]$, and in some cases, it is traditional medicine practitioners and local healers that promote and maintain introduced species within these communities [83-85]. This demonstrates the importance of valuing the knowledge and use of wild species and native domesticated species. At the same time, we found that there is greater knowledge of native and wild medicinal plants of the TDF among ELC inhabitants. This occurs because the lesser degree of urbanization results in closer proximity to wild vegetation, which favors the recognition and use of natural resources in daily life and delays the negative consequences of urbanization processes that tend to reduce human contact with their natural surroundings [11].

\section{Variables that influence the degree of knowledge of medicinal plants}

The degree of knowledge of medicinal plants differed between the two communities (Table 2) and was affected mainly by socioeconomic variables and the age of the interviewees, the way in which they acquired medicinal plants (collection or purchase), and the number of native, introduced, wild, and domesticated plants they named (Table 4). This agrees with the assertion of Rangel de Almeida and collaborators, who explained that geographic proximity among communities is a crucial factor for their similarity in botanical knowledge [84], as occurs in our study area, where both communities are surrounded by the same type of vegetation. These differences are expressed in the type and source of the resources that are known to each group. In ELC, the people with the most knowledge of the local flora were those that work in the primary sector. In contrast, in TGO, although there was a great deal of knowledge of medicinal plants, they were most knowledgeable about exotic and domesticated plants and tended to work in the tertiary sector. These results agree with previous findings from other investigations, in which a lower level of local botanical knowledge was related to nonagricultural employment and decrease in activities related to extraction of natural resources [11].

Complementary to these differences in traditional botanical knowledge (Table 2), our findings reveal an overlap in the knowledge of medicinal plants. This can be explained by the existence of an urbanization gradient, as well as by the fact that the method of analysis compared intrinsic differences between regions within each study community (Fig. 4). These overlaps occur among most of the regions we designated, but are particularly frequent between residents of the central and peripheral regions of TGO. This may be due to family dynamics, since many people inherit plots of land from their parents which are found on the outskirts of these communities. In contrast, in ELC, homes tend to be situated on large plots of land that house the entire extended family, including children and even grandchildren. Therefore, the difference in knowledge of medicinal plants of the inhabitants of this less urbanized community could be 
due to the complex dynamics of migration and the establishment of people from different communities.

On the other hand, the differences in knowledge of medicinal plants could also be due to the occupation of the interviewees. While homemakers in TGO apparently mentioned a large number of medicinal plants, these were mostly purchased and introduced, which could be due to their openness to commerce, since they are the member of the family that tends to attend markets to sell farm and other products (Table 6). On the other hand, the people whose occupation was in the primary sector used more wild, collected, and domesticated native species. This is consistent with findings of BeltránRodríguez and collaborators with respect to the idea that agriculture and livestock husbandry contribute to ethnobotanical knowledge, unlike those who work in commerce or service industries, which know more introduced species [69].

While it has been reported that people who work in the tertiary sector and who have higher economic income may have more knowledge of medicinal plants, it has also been observed that a considerable proportion of that knowledge is of introduced species [84, 86], which suggests that westernization and urbanization tend to homogenize local knowledge and diminish the biocultural richness of rural communities, putting at risk knowledge of medicinal plants and their natural environment [87]. The dominant culture legitimizes certain types of knowledge and practices deemed valid and desirable [88], to the point of social coercion. For example, the official health policies in Mexico often condition access to subsidies or benefits from social programs upon regular attendance of official health services, especially for inhabitants of less urbanized communities. With the understanding that culture and knowledge are flexible and dynamic, it is well known that some traditional practices are devalued by the dominant culture, which leads to transformation and erosion of experiences and knowledge of the management of the landscape and its resources [89]. For this reason, it is fundamentally important to preserve the knowledge and practices associated with the management of the natural environment, since they would disappear if there is no longer a relationship between human communities and natural elements, leading to the erosion of knowledge associated with natural resources [11, 33], the abandonment of their use [68] and their progressive loss [26].

\section{Threats to the continuity of use of medicinal plants in the urbanization gradient}

The increasing urbanization of TGO promoted by regional migration of inhabitants from ELC to this community, as well as the constant flux of migrants between TGO and the USA could negatively affect the consumption of medicinal or other useful plant species in the region in both localities by bringing allopathic medicines or natural remedies from elsewhere, which could contribute to the destabilization of traditional identity paradigms [90]. In some studies, it has been shown that this effect can lead to cultural change, which modifies the knowledge and perception of medicinal and edible plant resources [10, 27, 79, 91].

The preference for the use of medicinal plants as a preventative method in ELC may respond to the fact that inhabitants must invest more time and money to travel to another community to receive healthcare services. Often, in order to access subsidies or benefits from the social programs of the different levels of government, the inhabitants of less urbanized communities must demonstrate that they go to official health services. This has not necessarily been reflected in an improvement in health care. Rather, it has become a mechanism by which medical personnel, some of whom have strong prejudices and are not embedded in the local culture, dismiss the remedies and preventive care derived from traditional medicine. Since physicians are viewed as an authority in many Mexican towns, in the long term, the undervaluation of traditional medicine compared to allopathic medicine becomes cemented in people's minds. These dispositions may act as social coercion mechanisms that promote the devaluation of traditional therapies by official healthcare systems, which has negative implications for the appreciation and knowledge of medicinal plants $[27,78,92]$.

In the case of ELC, the transmission of knowledge of medicinal plants is being lost, probably due to the migration of young people. Since this transmission depends on the collective memory of the communities, there is increasing tolerance of the progressive loss of knowledge of plant resources $[26,90]$. It is important to mention that the key informants from ELC do not consider themselves traditional medicine practitioners, despite possessing a large body of knowledge of medicinal plants. This may imply that they do not consider it important to transmit their knowledge to others, leading to a process of colonization of the native epistemologies. This involves the dispossession and devaluing of knowledge and of the cultural foundations of indigenous, mestizo, and rural communities by the imposition of hegemonic models in multiple aspects of community life, in particular, healthcare [93-95].

The loss of this knowledge, according to interviewees, is mainly due to the speed with which allopathic medicines work and the pressure exerted by the healthcare system to disincentivize the use of medicinal plants. Both factors could result in the disuse of local resources, and therefore, disinterest in conserving them. PérezNicolás and collaborators have suggested that medicinal 
plants cannot be used to foment forest conservation [96]. However, the case of the Flora Sanctuary Orito Ingi Ande in Colombia is an example that this is possible, since in 2008, the government and the indigenous community agreed to conserve the biodiversity, including many medicinal plants, and the associated traditional knowledge [97]. It is therefore important to find mechanisms that allow synergy between traditional and western healing systems. This could maintain traditional knowledge and positive valorization of natural resources, playing a positive role in the communities and the conservation of their surroundings $[78,98]$.

In $\mathrm{TGO}$, traditional practices had an important presence in daily life and in symbolic aspects of community life. This is reflected by the knowledge possessed by its inhabitants of medicinal plants, and we therefore found a larger number of key informants that consider themselves traditional medicine practitioners. Although in both communities traditional practices are used to improve health, the cultural processes are very dynamic due to interaction with other cultures [88].

In $\mathrm{TGO}$, people receive economic benefits from the use of medicinal plants, be it by collecting them, using them in traditional medicine, or using them as a cheaper alternative to allopathic medicine. This coincides with the assertion by Shackleton and collaborators that nontimber forest products are vital components for local use as well as for sale in local and regional economies [99].

The inhabitants of TGO spend less time and money to visit a health clinic and use a wider variety of forms of treatment than in ELC. We consider that having access to more healthcare options in TGO allows people to try different healing methods. In the case of ELC, it may be that since there are fewer options for treatment and lower income, in addition to a strong effect of coercion by health policies, the value of knowledge of medicinal plants decreases, with negative repercussions for their use.

Characterizing and attempting to explain complex phenomena in depth, such as the effect of urbanization on knowledge of medicinal plants, requires an interdisciplinary approach. This research highlights the value and utility of knowledge that is maintained in rural communities about their surroundings, evidencing the implications for the conservation of local flora, specifically species with medicinal uses.

\section{Conclusions}

Knowledge of medicinal flora is diverse and dynamic, and can often be eroded by sociocultural processes like urbanization. This study shows the complexity of the phenomenon, since communities with a higher degree of urbanization can be a catalyst for the acquisition of a new set of knowledge, treatments, and forms of preparation. However, these innovations can be detrimental to the use of native flora, local knowledge systems, and their mechanisms of transmission. In this study, while the less urbanized community recognized a lower total number of medicinal plants, these were mostly native plants distributed in the surrounding vegetation. This could maintain links with and dependency on the local forest, which could stimulate conservation of important areas of tropical dry forest. Strong threats to the use of medicinal plants are evident due to complex processes, such as migration and contradictory public policy, which can erode biocultural heritage of traditional peoples.

\section{Acknowledgements}

We appreciate the support of the authorities and inhabitants of the communities of ELC and TGO. The authorities of the REBIOSH were always supportive of this research. Thanks to A. B. Maldonado for facilitating contact with the authorities in TGO. We thank Nextia Multimedia and the Sistema de Archivos Compartidos UAEM-3Ríos for the photographs.

\section{Authors' contributions}

CAG-Gathered and analyzed theoretical information, applied and analyzed interviews and did the field work, analyzed quantitative and qualitative results and helped to produce the perceptions map; JB- constructed theoretical and methodological frameworks, analyzed quantitative information; LBR- Revised the manuscript and analyzed quantitative information; $\mathrm{CL}$ - Revised the manuscript and was fundamental in the urbanization theoretical construction and in identifying the studied localities; HCB- Revised the manuscript and strengthened methodology; AIMC- Revised the manuscript and provided integrated and useful insights on results analyses and interpretations; JASH- Revised the manuscript and provided integrated and useful insights on results analyses and interpretations; XLMconstructed theoretical and methodological frameworks, analyzed qualitative information and elaborated responses maps. The authors read and approved the final manuscript.

\section{Funding}

This work was carried out with the support of scholarship CONACyT No. 447597.

\section{Availability of data and materials Not applicable.}

\section{Declarations}

\section{Ethics approval and consent to participate}

Specific ethical approval was not required because our research did not involve any sample collection from individuals, only asking questions and interviewing them, with their consent, in their homes. Local authorities (Comisariado ejidal) were approached by our group to ask for their authorization to interview the inhabitants of their localities, which they granted, and the project was presented to the inhabitants of each community in a general meeting prior to the study. All research inquiries were performed following the Ethics code of the SOLAE (Sociedad Latinoamericana de Etnobiología). We have included the authorization letters signed by the local authorities as supplementary information.

\section{Consent for publication}

Not applicable.

\section{Competing interests}

The authors declare that they have no competing interests.

\section{Author details}

${ }^{1}$ Centro de Investigación en Biodiversidad y Conservación (CIByC), Universidad Autónoma del Estado de Morelos, Av. Universidad 1001, Colonia

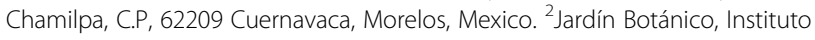
de Biología, Universidad Nacional Autónoma de México, Tercer Circuito exterior, S/N Ciudad Universitaria, Coyoacán, C.P, 04510 Mexico City, Mexico. 
${ }^{3}$ Centro de Investigaciones Tropicales (CITRO), Universidad Veracruzana, José María Morelos 44, Zona Centro, Centro, C.P. 91000, Xalapa-Enríquez, Veracruz, Mexico. ${ }^{4}$ Centro de Investigaciones Biológicas (CIB), Universidad Autónoma del Estado de Morelos, Av. Universidad 1001, Colonia Chamilpa, C.P, 62209 Cuernavaca, Morelos, Mexico. ${ }^{5}$ Escuela de Estudios Superiores - Campus Morelia, Universidad Nacional Autónoma de México, Antigua Carretera a Pátzcuaro 8701, Residencial San José de la Huerta, C.P, 58190 Morelia, Michoacán, Mexico. ${ }^{6}$ People and Plants International, Bristol, VT 05443, USA.

\section{Received: 18 March 2021 Accepted: 17 July 2021}

\section{Published online: 03 August 2021}

\section{References}

1. Medin DL, Atran S. Folkbiology. Massachusetts: Institute of Technology Press; 1999. https://doi.org/10.7551/mitpress/3042.001.0001.

2. Nesheim I, Dhillion SS, Stolen KA. What happens to traditional knowledge and use of natural resources when people migrate? Hum Ecol. 2006;34(1): 99-131. https://doi.org/10.1007/s10745-005-9004-y.

3. Gómez-Baggenthun E, Reyes-García V. Reinterpreting change in traditional ecological knowledge. Hum Ecol. 2013;41(4):643-7. https://doi.org/10.1007/ s10745-013-9577-9.

4. Reyes-García V, Guèze M, Luz AC, Paneque-Gálvez J, Macía MJ, Orta-Martínez $\mathrm{M}$, et al. Evidence of traditional knowledge loss among a contemporary indigenous society. Evo Hum Beh. 2013;34(4):249-57. https://doi.org/10.10 6/j.evolhumbehav.2013.03.002.

5. Murdock G. Procesos del cambio cultural. In: Shapiro H, editor. Hombre, cultura y sociedad. México: Fondo de Cultura Económica; 1975. p. 348-62.

6. Naylor L. Culture and change: an introduction: Greenwood publishing group; 1996.

7. Maffi L. Linguistic, cultural, and biological diversity. Annu Rev Anthropol. 2005;34(1):599-617. https://doi.org/10.1146/annurev.anthro.34.081804.12043 7.

8. Pretty J, Adams B, Berkes F, de Athayde SF, Dudley N. The intersections of biological diversity and cultural diversity: towards integration. Conserv Soc. 2009;7(2):100.

9. Pagaza CEM. Efecto de la urbanización y el cambio cultural en la estructura florística de los huertos familiares y su papel en la conservación de especies silvestres. Un estudio de caso en Tlacuilotepec, Puebla. México: MS Thesis, Universidad Nacional Autónoma de México; 2008.

10. Cano-Ramírez M, De la Tejera B, Casas A, Salazar L, García BR. Migración rural y huertos familiares en una comunidad indígena del centro de México. Bot Sci. 2012;90(3):287.

11. Saynes-Vásquez A, Caballero J, Meave AJ, Chiang F. Cultural change and loss of ethnoecological knowledge among the Isthmus Zapotecs of Mexico. J Ethnobiol Ethnomed. 2013;9(40):1.

12. Villalvazo-Peña P, Corona JP, García S. Urbano-Rural, constante búsqueda de fronteras conceptuales. Rev Infor An. 2002;20:17.

13. Foster GM. Traditional cultures and the impact of technological change. New York: Harper y Row; 1962.

14. Berkowitz AR, Nilon $\mathrm{CH}$, Hollweg KS. Understanding urban ecosystems. New York: SpringerNerlag; 2003

15. Tapia CE, Vargas-Uribe G. El impacto del desarrollo urbano en los recursos naturales. Morelia: CIDEM-UMSNH; 2006.

16. Faeth SH, Warren PS, Shochat E, Marussich WA. Trophic dynamics in urban communities. BioScience. 2005;55(5):399-407 http://doi.org/10.1641/00063568(2005)055[0399:tdiuc]2.0.co;2?refregid=search-gateway: bc7ead126b6b4e117720a38cb8e74b83.

17. Vitousek PM, Mooney HA, Lubchenco J, Melillo JM. Human domination of Earth's ecosystems. Science. 1997;277(5325):494-9. https://doi.org/10.1126/ science.277.5325.494.

18. Collins JP, Kinzig A, Grimm NB, Fagan WF, Hope D, Wu J, et al. A new urban ecology. American Scientist. 2000;88:416-25.

19. Alberti M, Marzluff JM, Shulenberger E, Bradley G, Ryan C, Zumbrunnen C. Integrating humans into ecology: opportunities and challenges for studying urban ecosystems. BioScience. 2003;53(12):1169-79. https://doi.org/10.1641/ 0006-3568(2003)053[1169:IHIEOA]2.0.CO;2.

20. Hawkes C. Uneven dietary development: linking the policies and processes of globalization with the nutrition transition, obesity and diet-related chronic diseases. Globalization Health. 2006;2(1):4-18. https://doi.org/10.11 86/1744-8603-2-4
21. Poot-Poll W. Composición, estructura y medios de vida en los huertos en la parte norte de Campeche. México: PhD Thesis, El Colegio de la Frontera Sur; 2015.

22. Turreira-García N, Vilkamaa AM, Byg A, Theilade I. Diversity, knowledge, and use of leafy vegetables in Northern Thailand-maintenance and transmission of ethnobotanical knowledge during urbanisation. NAT HIST BULL SIAM SOC 2017;62(1):85-105.

23. Pyle RM. The thunder tree: lessons from an urban wildland. Boston: Houghton Mifflin; 1993.

24. Benz FB, Cevallos EJ, Santana MF, Rosales AJ, Graf MS. Losing knowledge about plant use in the Sierra de Manantlán Biosphere Reserve. Mexico. Eco Bot. 2000;54(2):183-91. https://doi.org/10.1007/BF02907821.

25. Agelet A, Valles J. Studies on pharmaceutical ethnobotany in the region of Pallars (Pyrenees, Catalonia, Iberian Peninsula). Part I. General results and new or very rare medicinal plants. J Ethopharmacol. 2001;77(1):57.

26. Sáenz-Arroyo A, Roberts CM, Torre J, Cariño-Olvera M, Enríquez-Andrade R. Rapidly shifting environmental baselines among fisher of the Gulf of California. Proc Roy Soc Biol Sci. 2005;272(1575):1957.

27. Aslam M, Ahmad M. Worldwide Importance of medicinal plants: current and historical perspectives. Rec Adv Biol and Med. 2016;2:88. https://doi. org/10.18639/RABM.2016.02.338811.

28. OMS. Nuevas directrices de la OMS para fomentar el uso adecuado de las medicinas tradicionales. http://www.who.int/mediacentre/news/releases/2 004/pr44/es/. Accessed 13 April 2004.

29. Bye R, Linares E. Usos pasados y presentes de algunas plantas medicinales encontradas en los mercados mexicanos. Am Indíg. 1987;47(2):200.

30. Ellen R, Lycett SJ, Johns SE. Understanding cultural transmission in anthropology, a critical synthesis. New York: USA. Berghahn books; 2013.

31. Blancas J, Casas A, Pérez-Salicrup D, Caballero J, Vega E. Ecological and socio-cultural factors influencing plant management in Náhuatl communities of the Tehuacán Valley, Mexico. J Ethnobiol Ethnomed. 2013; 9(1):39. https://doi.org/10.1186/1746-4269-9-39.

32. Martínez-Ballesté A, Martorell C, Caballero J. Cultural or ecological sustainability? The effect of cultural change on Sabal palm management among the lowland Maya of Mexico. Ecol Soc. 2006;11(2):27.

33. Toledo VM, Boege E, Barrera-Bassols N. The biocultural heritage of Mexico: a case study. In: Maffi L Harmon Ds. An introduction to biocultural diversity. Report of the international conference on biological and cultural diversity for development biocultural diversity toolkit. Tenth Meeting of the Conference of the Parties to the Convention on Biological Diversity (CBD COP 10), Nagoya, Japan, 2010.

34. Beltrán-Rodríguez L, Manzo-Ramos F, Maldonado-Almanza B, MartínezBallesté A, Blancas J. Wild medicinal species traded in the Balsas Basin, Mexico: risk analysis and recommendations for their conservation. J Ethnobiol. 2017;37(4):743. https://doi.org/10.2993/0278-0771-37.4.743.

35. Boege SE. El Patrimonio biocultural de los pueblos indígenas de México. México: Instituto Nacional de Antropología e Historia; 2008.

36. OECD. Reviews of Health Systems: Mexico 2016, OECD reviews of health systems, OECD Publishing, Paris, https://doi.org/10.1787/9789264230491-en. Accessed in 16 July 2016.

37. United Nations. World urbanization prospects: the 2018 revision. Department of Economic and Social Affairs, Population Division. Online Edition; 2018.

38. FAO. El estado de los bosques del mundo-Las vías forestales hacia el desarrollo sostenible. Roma. Licencia: CC BY-NC-SA 3.0 IGO; 2018.

39. CONANP. Programa de Conservación y Manejo de la Reserva de la Biosfera Sierra de Huautla. http://www2.inecc.gob.mx/publicaciones/consultaPublica cion.html? id\%20pub=551, Accessed 3 January 2005

40. Osorio-Beristain M. Origen, evolución y ecología de la selva seca. Inventio. 2012;16(8):61.

41. Hersch-Martínez P. Commercialization of wild medicinal plants from Southwest Puebla, Mexico. Economic Botany. 1995;49(2):197-206. https:// doi.org/10.1007/BF02862925

42. Hersch-Martínez P. Medicinal plants and regional traders in Mexico: physiographic differences and conservational challenge. Economic Botany. 1997;51(2):107-20. https://doi.org/10.1007/BF02893100.

43. Hersch-Martínez P. Plantas medicinales silvestres del suroccidente poblano y su colindancia en Guerrero, México: rutas de comercialización, antecedentes y dinámica actual. In: Long Y, Attolini A, editors. coord. Caminos y mercados de México. México: INAH-UNAM; 2009. p. 665-86.

44. Abad-Fitz I, Maldonado-Almanza B, Aguilar-Dorantes KM, Sánchez-Méndez L, Gómez-Caudillo L, Casas A, et al. Consequences of traditional management 
in the production and quality of copal resin (Bursera bipinnata (Moc. \&amp; Sessé ex DC.) Engl.) in Mexico. Forests. 2020;11(9):991. https://doi.org/10.33 90/f11090991.

45. Solares AF. Etnobotánica y usos potenciales del Cirián (Crescentia alata, H.B. K.) en el estado de Morelos. Polibotánica. 2004;18:13-31.

46. Hersch-Martínez P. Perspectivas de la producción de linóleo. In: Estado del desarrollo económico y social de los pueblos indígenas de Guerrero. UNAM, Secretaría de Asuntos indígenas del Gobierno del Estado de Guerrero, México; 2009.

47. Argueta A. El estudio de los Tianguis y Mercados en México. Etnobiología. 2016;14(2):38-46.

48. Rzedowski J. Vegetación de México. México: Comisión Nacional para el Conocimiento y Uso de la Biodiversidad; 2006

49. INEGI, Censo de Población y Vivienda. http://www3.inegi.org.mx/sistemas/ iter/default.aspx?ev=5. 2010a. Accessed 16 July 2015.

50. CONAPO. Índice de Marginación Urbana 2010. http://www.conapo.gob.mx/en/ CONAPO/Indice_de_marginacion_u rbana_2010. Accessed 4 February 2010.

51. Maldonado-Almanza BJ. Aprovechamiento de los Recursos Florísticos de la Sierra de Cuautla, Morelos, México. Morelos: MS Thesis, Facultad de Ciencias, Universidad Nacional Autónoma de México; 1997.

52. INEGI. Directorio Estadístico Nacional de Unidades Económicas. 2010b. http://www.inegi.org.mx/est/contenidos/proyectos/denue/presentacion.a spx. Accessed 16 July 2015.

53. Bernard H. Métodos de Investigación en Antropología. Abordajes cualitativos y Cuantitativos. Estados Unidos de América: AltaMira Press; 1995.

54. Baxter J, Eyles J. Evaluating qualitative research in social geography: establishing "rigour" in interview analysis. Trans Inst Brit Geog. 1997;22(4): 505-25. https://doi.org/10.1111/j.0020-2754.1997.00505.X.

55. Aguilar A, Camacho JR, Chino S, Jacques P, López M. Herbario medicinal del Instituto Mexicano del Seguro Social (IMSS). México DF: Información etnobotánica; 1994.

56. Corp IBM. Released. IBM SPSS Statistics for Windows, Version 24.0. Armonk: IBM Corp; 2016.

57. Long N. Introduction. In: Long N, Long A, editors. Battlefields of knowledge: the interlocking of theory and practice in social research and development. London.: Routledge; 1992. p. 3-15.

58. Denzin NK, Lincoln YS. The landscape of qualitative research. Thousand Oaks: Sage Publications; 2008

59. O'Neill RV. Is it time to bury the ecosystem concept? (With full military honors, of course!). Ecology. 2001;82(12):3275e3284.

60. Durand L. De las percepciones a las perspectivas ambientales: una reflexión teórica sobre la antropología y la temática ambiental. Nuev antrop. 2008; 21(68):75.

61. Friese S. ATLAS.ti 7.5 User Guide and Reference [Software]. Berlin: Scientific Software Development GmbH. 427 p. 2015

62. Waltner-Toews D, Kay JJ, Neudoerffer C, Gitau T. Perspective changes everything: managing ecosystems from the inside out. Front Ecol Environ. 2003;1(1):23e30.

63. López-Medellín X, Castillo A, Ezcurra E. Contrasting perspectives on mangroves in arid Northwestern Mexico: implications for integrated coastal management. Ocean Coas Manage. 2011;54(4):318-29. https://doi.org/10.1 016/j.ocecoaman.2010.12.012

64. López-Medellín X, Vázquez LB, Valenzuela-Galván D, Wehncke E, Maldonado-Almanza $B$, et al. Percepciones de los habitantes de la reserva de la Biosfera Sierra de Huautla: Hacia el Desarrollo de nuevas estrategias de manejo participativo. Interciencia. 2017:42(1):8.

65. Camacho-Cervantes M, Schöndube JE, Castillo A, MacGregor-Fors I. How do people perceive urban trees? Assessing likes and dislikes in relation to the trees of a city. Urb ecos. 2014;17(3):761-73. https://doi.org/10.1007/s11252014-0343-6.

66. Beltrán-Rodríguez L, García-Madrid I, Saynes-Vásquez A. Apropiación cultural de una planta europea en la herbolaria tradicional mexicana: el caso del Ajenjo (Artemisia absinthium L. ASTERACEAE). Revista Etnobiología. 2017; 15(2):46.

67. Valenzuela-Galván D, Dorado O, Ramírez R. Sierra de Huautla, Morelos, Guerrero y Puebla. In: Ceballos G, Martínez L, García A, Espinoza E, Bezaury J, Dirzo R, editors. Diversidad, Amenazas y Regiones Prioritarias para la Conservación de las Selvas Secas del Pacífico de México. México: D.F.FCE/ CONABIO/CONANP; 2010.

68. Linares $\mathrm{E}$, Bye R. La dinámica de un mercado periférico de plantas medicinales de México: el tianguis de Ozumba, Estado de México, como centro acopiador para el mercado de Sonora (mercado central). In: Long TJ, Attolini LA, editors. Caminos y Mercados de México. México: Universidad Nacional Autónoma de México/ Instituto de Investigaciones Históricas / Instituto Nacional de Antropología e Historia; 2009. p. 631.

69. Beltrán-Rodríguez L, Ortiz-Sánchez A, Mariano AN, Maldonado-Almanza B, Reyes-García V. Factors affecting ethnobotanical knowledge in a mestizo community of the Sierra de Huautla Biosphere Reserve, Mexico. J Ethnobiol Ethnomed. 2014;10(14):1.

70. Saldanha GLR, Farias PRL, Albuquerque PU. Knowledge and use of medicinal plants by local specialists in a region of Atlantic Forest in the state of Pernambuco (Northeastern Brazil). J Ethnobiol Ethnomed. 2005;1(9): 1.

71. Caballero J, Cortés L. Percepción, uso y manejo tradicional de los recursos vegetales en México. In: Rendón B, Rebollar JS, Caballero J, Martínez MA, editors. Plantas Cultura y Sociedad. México: Universidad Autónoma de Metropolitana / SEMARNAP; 2001. p. 79.

72. Blancas J, Caballero J, Beltrán-Rodríguez L. Los Productos Forestales No Maderables en México. Fascículo 1. Panorama General. México: Red Temática de Productos Forestales No Maderables / Consejo Nacional de Ciencia y Tecnología; 2017. p. 12-8.

73. Caballero J, Casas A, Cortés L, Mapes C. Patrones en el conocimiento, uso y manejo de plantas en pueblos indígenas de México. Est Atacam. 1998;16: 181.

74. Monroy-Ortíz C, Castillo-España P. Plantas medicinales utilizadas en el estado de Morelos. México: Comisión Nacional para el Conocimiento y Uso de la Biodiversidad / Universidad Autónoma del Estado de Morelos; 2007.

75. Hersh-Martínez P. La Flora medicinal en comunidades indígenas. In: Estado del desarrollo económico y social de los pueblos indígenas de Guerrero. México. http://www.nacionmulticultural.unam.mx/edespig/diagnostico_y_ perspectivas/RECUAD. Accessed 23 November 2015: Programa Universitario México Nación Multicultural UNAM y Secretaria de Asuntos Indígenas del Gobierno del Estado de Guerrero; 2009.

76. Gobierno de Tepalcingo, Plan municipal de desarrollo (2016-2018). http:// marcojuridico.morelos.gob.mx/archivos/reglamentos_estatales/pdf/PLA NDESTEPALCINGO2016-2018.pdf. 2016. Accessed 16 July 2015.

77. Ceuterick M, Vandebroek I, Torry B, Pieroni A. Cross-cultural adaptation in urban ethobotany: the Colombian folk pharmacopoeia in London. J Ethonopharm. 2008;120(3):342-59. https://doi.org/10.1016/j.jep.2008.09.004

78. Giovannini P, Reyes-García V, Waldstain A, Heinrich M. Do pharmaceuticals displace local knowledge and use of medicinal plants? Estimates from a cross-sectional study in a rural indigenous community. Mexico Soc Sci Med. 2011;72(6):928-36. https://doi.org/10.1016/j.socscimed.2011.01.007.

79. Vandebroek I, Balick MJ. Globalization and loss of plant knowledge: challenging the paradigm. Plos One. 2012;7(5):e37643. https://doi.org/10.13 71/journal.pone.0037643.

80. Blair BR. Land use and avian species diversify along an urban gradient. Ecol App. 1996;6(2):506-19. https://doi.org/10.2307/2269387.

81. Lozano A, Araújo EL, Medeiros MFT, et al. The apparency hypothesis applied to a local pharmacopoeia in the Brazilian northeast. J Ethnobiol Ethnomedicine. 2014;10(2). https://doi.org/10.1186/1746-4269-10-2.

82. Alencar N, Araújo TAS, Amorim EL, Albuquerque UP. The inclusion and selection of medicinal plants in traditional pharmacopoeias - evidence in support of the diversification hypothesis. Economic Botany. 2010;64(1):6879. https://doi.org/10.1007/s12231-009-9104-5.

83. Voeks RA, Leony A. Forgetting the forest: assessing medicinal plant erosion in Eastern Brazil. Ecol Bot. 2004;58(1):294.

84. de Almeida CFCB R, Alves-Ramos M, AEL C, Paulino-de Albuquerque U. A comparison of knowledge about medicinal plants for three rural communities in the semi-arid region of northeast of Brazil. J Ethnopharm. 2009;127:674.

85. Oliveira-Campos LZ, Albuquerque-Paulino U, Peroni N, Araújo EL. Do socioeconomic characteristics explain the knowledge and use of native food plants in semiarid environments in Northeastern Brazil? J Arid Environ. 2015;115:53-61. https://doi.org/10.1016/j.jaridenv.2015.01.002.

86. Caniago I, Siebert SF. Medicinal plant ecology, knowledge and conservation in Kalimantan, Indonesia. Econ Bot. 1998;52(3):229-50. https://doi.org/10.1 007/BF02862141.

87. Monroy-Martínez R, García FA, Monroy-Ortiz C. Plantas útiles de los huertos frutículas tradicionales de Coatetelco, Morelos, México, frente al potencial emplazamiento minero. Acta agrícola y pecuaria. 2017;3(3):87. 
88. Bonfil-Batalla G. Nuestro patrimonio cultural: Un laberinto de significados. In: Aceves B, García-Calderón PA, editors. Patrimonio cultural y turismo. Cuadernos. Pensamientos acerca del patrimonio cultural. Antología de Textos. México: D.F.Consejo Nacional para la Cultura y las Artes/ Coordinación de Patrimonio Cultura y Turismo; 2003.

89. Guevara S. Las reservas de biosfera en Iberoamérica. Ambienta. 2010;92:46.

90. Szurmuk M, Mckee-Irwin R. In: XXI S, editor. Diccionario de Estudios Culturales Latinoamericanos. México: Instituto Mora; 2009.

91. Muniz de Medeiros P, Taboada-Soldati G, Leal-Alencar N, Vandebroek I, Pieroni A, et al. The use of medicinal plants by migrant people: adaptation, maintenance, and replacement. Evid Based Complement Alternat Med. 2012;11. https://doi.org/10.1155/2012/807452

92. García-Canclini N. Introducción: La Sociología de la Cultura de Pierre Bourdieu. In: Bourdieu P, editor. . México: Sociología y Cultura. Consejo Nacional para la Cultura y las Artes/Grijalbo; 1990. p. 9-51.

93. De Sousa-Santos B. Descolonizar el saber, reinventar el poder. Montevideo, Uruguay: Trilce-Extensión Universitaria; 2010.

94. Correa-Muñoz ME, Saldarriaga-Grisales DC. El epistemicidio indígena latinoamericano, algunas reflexiones desde el pensamiento crítico decolonial. Revista CES Derecho. 2014;2(5):154

95. Rivera-Cusicanqui S. Hambre de huelga. La Paz, Bolivia: La Mirada Salvaje; 2014.

96. Pérez-Nicolás M, Vibrans H, Romero-Manzanares A. Can the use of medicinal plants motivate forest conservation in the humid mountains of Northern Oaxaca, Mexico? Bot Sci. 2018;96(2):267. https://doi.org/10.17129/botsci.1 862.

97. Dudley N, Groves C, Redford KH, Solton S. Where now for protected areas? Setting the stage for the 2014 World Parks Congress. Oryx. 2014;48(4):496503. https://doi.org/10.1017/50030605314000519.

98. Dustin BC, Ghimire K. Synergy between traditional ecological knowledge and conservation science supports forest preservation in Ecuador. Conserv Ecol. 2003;8(1):1.

99. Shackleton CM, Pandey AK, Ticktin T. Ecological sustainability for non-timber forest products: dynamics and case studies of harvesting. New York: Routledge; 2015.

\section{Publisher's Note}

Springer Nature remains neutral with regard to jurisdictional claims in published maps and institutional affiliations.

Ready to submit your research? Choose BMC and benefit from:

- fast, convenient online submission

- thorough peer review by experienced researchers in your field

- rapid publication on acceptance

- support for research data, including large and complex data types

- gold Open Access which fosters wider collaboration and increased citations

- maximum visibility for your research: over $100 \mathrm{M}$ website views per year

At $\mathrm{BMC}$, research is always in progress.

Learn more biomedcentral.com/submissions 